\title{
The Disease-Associated Chaperone FKBP51 Impairs Cognitive Function by Accelerating AMPA Receptor Recycling
}

\author{
[DLaura J. Blair, ${ }^{1}$ (D) Marangelie Criado-Marrero, ${ }^{1}$ Dali Zheng, ${ }^{1}$ Xinming Wang, ${ }^{2}$ Siddharth Kamath, ${ }^{1}$ \\ Bryce A. Nordhues, ${ }^{1}$ [D Edwin J. Weeber, ${ }^{2}$ and Chad A. Dickey ${ }^{\S}$
}

https://doi.org/10.1523/ENEURO.0242-18.2019

${ }^{1}$ Department of Molecular Medicine, University of South Florida, Byrd Institute, Tampa, FL 33613 and ${ }^{2}$ Department of Pharmacology and Physiology, University of South Florida, Byrd Institute, Tampa, FL 33613

\begin{abstract}
Increased expression of the FK506-binding protein 5 (FKBP5) gene has been associated with a number of diseases, but most prominently in connection to psychiatric illnesses. Many of these psychiatric disorders present with dementia and other cognitive deficits, but a direct connection between these issues and alterations in FKBP5 remains unclear. We generated a novel transgenic mouse to selectively overexpress FKBP5, which encodes the FKBP51 protein, in the corticolimbic system, which had no overt effects on gross body weight, motor ability, or general anxiety. Instead, we found that overexpression of FKBP51 impaired long-term depression (LTD) as well as spatial reversal learning and memory, suggesting a role in glutamate receptor regulation. Indeed, FKBP51 altered the association of heat-shock protein 90 (Hsp90) with AMPA receptors, which was accompanied by an accelerated rate of AMPA recycling. In this way, the chaperone system is critical in triage decisions for AMPA receptor trafficking. Imbalance in the chaperone system may manifest in impairments in both inhibitory learning and cognitive function. These findings uncover an unexpected and essential mechanism for learning and memory that is controlled by the psychiatric risk factor FKBP5.
\end{abstract}

Key words: AMPA receptor; chaperone; FKBP5; Hsp90

\section{Significance Statement}

Candidate studies have identified a link between FK506-binding protein 5 (FKBP5) allelic variants and psychiatric disorders. Patients with these disorders often present with cognitive defects. FKBP5 variants have been correlated to decreased hippocampal volume, but a direct connection between FKBP5 and cognitive function has not been established. Here, we have found that mice with high levels of FKBP5 have altered reversal learning and memory, which may be through direct regulation of neuronal activity by regulating AMPA receptors.

\section{Introduction}

The 51-kDa FK506-binding protein (FKBP5/FKBP51) has been genetically linked to a number of disorders associated with affective symptoms as well as impair-

\footnotetext{
Received June 15, 2018; accepted February 1, 2019; First published February 13,2019

C.A.D. and L.J.B. are the co-inventors for the following patent application: "Transgenic mouse model for conditional fkbp51 expression and related methods." US Patent Application\# US20150327523 A1. All other authors declare no competing financial interests.
}

ments in learning and memory. FKBP5 expression can be enhanced by stress as well as common single nucleotide polymorphisms (SNPs; Klengel et al., 2013). These SNPs can increase suceptibility for post-traumatic stress disor-

Author contributions: L.J.B., E.J.W., and C.A.D. designed research; L.J.B., M.C.-M., D.Z., X.W., S.K., and B.A.N. performed research; L.J.B., M.C.-M., D.Z., X.W., S.K., and B.A.N. analyzed data; L.J.B. and C.A.D. wrote the paper. This work was funded by the National Institute of Mental Health Grant 1R01MH103848 and the National Institute of Neurological Disorders and Stroke Grant R01NS073899. 
der (PTSD; Klengel et al., 2013), major depression (Binder et al., 2004; Klengel et al., 2013), cognitive decline in aging (Fujii et al., 2014), suicide, aggression, and violent behavior (Binder et al., 2008; Bevilacqua et al., 2012). Moreover, FKBP5 expression progressively increases with normal aging, concomitant with reduced FKBP5 DNA methylation, and has been associated with the number one cause of dementia in the world, Alzheimer's disease (Jinwal et al., 2010; Blair et al., 2013; Sabbagh et al., 2014).

While some viral-mediated overexpression studies have attempted to model increased FKBP5 levels in the murine central nervous system, no stable transgenic models have been made. These viral studies have demonstrated that FKBP5 overexpression in the amygdala, but not the hippocampus, can increase anxiety-related behavior (Hartmann et al., 2015). However, conversely, viral-mediated knock-down of Fkbp5 in the amygdala prevented stressinduced fear (Attwood et al., 2011). Moreover, mice lacking the Fkbp5 gene show reduced hypothalamic-pituitaryadrenal (HPA) axis reactivity and protection from stressinduced (Touma et al., 2011; Hartmann et al., 2012) and age-induced (O'Leary et al., 2011) depressive-like behavior. These studies have highlighted potential roles for FKBP5/FKBP51 in aging, cognition, and disease. But a model to investigate the consequences of increased FKBP5 expression in the corticolimbic system has not been developed despite some of the clinical phenotypes clearly being related to learning and memory.

Here, we filled this gap by generating the first transgenic mouse to overexpress FKBP51 throughout the forebrain, beginning early in the post-natal period as determined by the expression pattern of CamKIl $\alpha$. FKBP51 overexpression had a pronounced, and previously unknown, effect on inhibitory learning and plasticity through altered AMPA receptor dynamics. Specifically, we identified that high levels of FKBP51 accelerated the recycling of internalized AMPA receptors back to the synaptic membrane. This may be due to direct interaction of FKBP51 with heat-shock protein 90 (Hsp90) while in complex with GluR1-type AMPA receptors, as our data suggests. In addition to allowing us to identify a critical mechanism that regulates fate decisions for GluR1-type AMPA receptors, these novel FKBP5-expressing mice could also be used in future studies to assess other FKBP51related phenotypes, particularly using stress or gene $\times$ environment paradigms, as well as to test the efficacy of emerging therapeutics designed to target FKBP51.

§Deceased, November 26, 2016

Acknowledgements: We thank Dr. Jessica Banko for her guidance on electrophysiology experiments, Noreen Luetteke for her advice and providing the plasmids the targeted insertion of FKBP5 into mice, and Bo Zhang and Matt Cockman for their contributions to generating the rTgFKBP5 mice.

Correspondence should be addressed to Laura J. Blair at Iblair@health.usf.edu.

https://doi.org/10.1523/ENEURO.0242-18.2019

Copyright (C) 2019 Blair et al.

This is an open-access article distributed under the terms of the Creative Commons Attribution 4.0 International license, which permits unrestricted use, distribution and reproduction in any medium provided that the original work is properly attributed.

\section{Materials and Methods}

\section{Antibodies and reagents}

pBT378 and pTR-tTA-GFP were a kind gift from Noreen Luetteke. pCl-SEP-GluR1 (plasmid \#24000) was purchased from Addgene. Human FKBP5 (Hs01551006_m1), Mouse Fkbp5 (mm00487406_g1), and mouse Gapdh (mm99999915_g1) Real-time PCR TaqMan probes were purchased from Applied Biosystems and used in combination with an RNA-to-C $\mathrm{C}_{\mathrm{T}}$ 1-Step kit (Applied Biosystems). All Antibodies used at 1:1000 unless otherwise indicated. The following antibodies were used: $\alpha$-GAPDH (Meridian Life Science catalog \#H86045M, RRID:AB_497737) and $\alpha$-FKBP51 (clone Hi51B) and $\alpha$-FKBP51 (clone Hi51E) antibodies were a kind gift from Marc Cox. Hi51B is the same clone that can be commercially purchased (StressMarq Biosciences catalog \#SMC-138, RRID:AB_2570356, Novus catalog \#NB110-96873, RRID: AB_1260804, or Abcam catalog \#ab79844, RRID: $\left.A B \_2103132\right)$. Clone Hi51E has been previously characterized (Nair et al., 1997; Gross et al., 2008). $\alpha$-GluR1 (Cell Signaling Technology catalog \#13185, RRID:AB_2732897), $\alpha$-glucocorticoid receptor (GR; Cell Signaling Technology catalog \#3660S, RRID:AB_11179215), biotin-conjugated $\alpha$-NeuN (Millipore catalog \#MAB377B, RRID:AB_177621), and $\alpha$-Hsp90 (StressMarq Biosciences catalog \#SMC-149, RRID:AB_2570363). The following HRP-tagged $\alpha$-mouse and $\alpha$-rabbit secondary antibodies were used for Western blottings (SouthernBiotech catalog \#1030-05, RRID:AB_2619742 and SouthernBiotech catalog \#4050-08, RRID:AB_2732896). The following BIOTlabeled $\alpha$-mouse secondary antibody (SouthernBiotech catalog \#1020-08, RRID:AB_2737411) was used for immunohistochemical staining. S-AMPA and NMDA were purchased from Tocris Bioscience.

\section{Construction of the rTgFKBP5 vector}

The responder transgene was generated by two subsequent subcloning steps. First, following the addition of a Pmel site by mutagenesis, we ligated human FKBP5 cDNA into Tet-Op-mp1 pA vector through digestion of the Clal and EcoRV cut sites. This plasmid, TetO-FKBP5, was subcloned into pBT378 through digestion by Pmel and Notl restrictions sites, which generated the final TgFKBP5 vector. This final vector (TgFKBP5) was used to generate site-specific FKBP5 transgenic founder mice on the FVB background. This was achieved, based on an established method (Tasic et al., 2011), by co-microinjection of the constructed TgFKBP5 and $\Phi$ C31 Integrase into H11P3 homozygous oocytes from fertilized $\mathrm{FVB} / \mathrm{N}$ mice which have attP insertion sites at the Hipp11 (H11) locus on chromosome 11 by the Stanford Transgenic Research Facility at Stanford University School of Medicine in Stanford, CA.

\section{Generation and genotyping of rTgFKBP5 mice}

Founder mice contained a single copy of FKBP5 which was inserted into the Hipp11 ( $\mathrm{H} 11)$ locus by irreversible recombination using $\Phi C 31$ integrase with complimentary attB and attP sites (Tasic et al., 2011). High expression of this single copy of FKBP5 was generated by crossing TgFKBP5 single-transgenic founder mice on the FVB background with CAMKII $\alpha$-tTA mice on the $129 \mathrm{~S} 6$ background 
(The Jackson Laboratory; stock 003010). Female FVB FKBP5 mice were bred with male CamKIl $\alpha$-tTA mice. The offspring of this cross generated the rTgFKBP5 doubletransgenic line, which are used for experiments only and not for further breeding. The founding strain is maintained by ordering FVB/NJ female mice (The Jackson Laboratory) to breed with male FKBP5 mice and the CamKIl $\alpha$-tTA strain is maintained in-house by ordering 129S6/SVEV female (Taconic) mice to breed with male CamKIl $\alpha$-tTA mice. Genotyping was performed using ear clip digests using the following primers: for the inserted human FKBP5 gene ( $F$, 5'GTGTACGGTGGGAGGCCTAT3', and R, 5'GTCCCATGCCTTGATGACTT3') and CamKIl $\alpha$-tTA (F, 5' -CGCTGTGGGGCATTTTACTTT-3', and R, 5'-CATGTCCAGATCGAAATGGTC-3' as well as for the housekeeping gene T-cell receptor $\delta$ chain (Tcrd; F, 5'-CAAATGTTGCTTGTCTGGTG-3', and R, 5'-GTCAGTCGAGTGCACAGTT-3') to confirm presence of tissue. DNA was amplified in a ThermoCycler (Thermo Scientific) with the following cycles: $15 \mathrm{~min}$ at $95^{\circ} \mathrm{C}, 20 \times 15 \mathrm{~s}$ at $95^{\circ} \mathrm{C}, 30$ $\mathrm{s}$ at $68^{\circ} \mathrm{C}, 45 \mathrm{~s}$ at $72^{\circ} \mathrm{C}$, and $10 \mathrm{~min}$ at $72^{\circ} \mathrm{C}$. The PCR product was then analyzed on a Quiaxcel (QIAGEN). Mice positive for both human FKBP5 and CamKII $\alpha$-tTA were classified as rTgFKBP5. Those positive for the CamKIl $\alpha$-tTA and lacking the human FKBP5 gene were classified as tTA, and mice lacking both genes were classified as wild type (WT).

\section{Tissue collection, brightfield staining, and microscopy}

All animal studies were approved and conducted following the guidelines set by the University of South Florida Institutional Animal Care and Use Committee in accordance with the Association for Assessment and Accreditation of Laboratory Animal Care international regulation. Both sexes of mice were used throughout all of the experiments. Body weight was measured multiple times over the lifespan of the mice by self-calibrating scale (Ohaus). For tissue collection and processing, mice were overdosed with pentobarbital solution and transcardially perfused with $0.9 \%$ saline solution; brains were rapidly removed and the left hemisphere was placed in 4\% paraformaldehyde overnight and the right hemisphere was snap frozen for Western blottings and RNA extraction. Free-floating sections were used for immunohistochemical analysis using 1:100 FKBP51 (Hi51B) antibody Extended data Fig. 2-1. Brightfield stained tissue was imaged by a Zeiss AxioScan.Z1 slide scanner using a $20 \times$ objective.

\section{Western blottings}

For Western blottings, mouse tissue was weighed and homogenized by sonication in RIPA buffer $(50 \mathrm{mM}$ Tris$\mathrm{HCl}, 150 \mathrm{mM} \mathrm{NaCl}, 2 \mathrm{mM}$ EDTA, $0.1 \%$ SDS, $0.5 \%$ sodium deoxycholate, and $1 \%$ Triton X-100; pH 7.4), except where indicated. A total of $10 \mu \mathrm{l}$ of buffer was added per $1 \mathrm{mg}$ of brain tissue. Equal amounts of protein, except where indicated, were run on SDS-PAGE gels (Bio-Rad) and processed by Western blotting.

\section{Real-time quantitative RT-PCR}

Frozen mouse brain cortex ( $\sim 30 \mathrm{mg})$ was placed into 1 $\mathrm{ml}$ TRIzol (Thermo Scientific) and was homogenized. Briefly, to each $1 \mathrm{ml}$ of TRIzol reagent, 200- $\mu$ l chloroform was added, mixed vigorously and incubated for $5 \mathrm{~min}$ at room temperature before centrifugation at $12,000 \times g$ $\left(4^{\circ} \mathrm{C}\right.$ for $\left.15 \mathrm{~min}\right)$. The upper aqueous layer was separated and added to 2.5 volumes of $100 \%$ ethanol. Incubated at $-20^{\circ} \mathrm{C}$ for $1 \mathrm{~h}$ following centrifugation at $12,000 \times g\left(4^{\circ} \mathrm{C}\right.$ for $15 \mathrm{~min})$. The supernatant was discarded and the pellet was washed with $1 \mathrm{ml} 75 \%$ ethanol following centrifugation at $10,000 \times g\left(4^{\circ} \mathrm{C}\right.$ for $\left.15 \mathrm{~min}\right)$. The supernatant was discarded and the pellet was dried carefully. The pellet was resuspended in RNase-free water. To get rid of genomic DNA contamination, total RNA was incubated with RNase-free DNasel on RNeasy spin columns (QIAGEN) for $15 \mathrm{~min}$ and eluted using RNase-free water and measured on Nanodrop 2000 (Thermo Scientific).

The real-time RT-PCR was done using TaqMan RNA-to $\mathrm{C}_{\mathrm{T}}$ 1-Step kit (Thermo Scientific) and GeneAmp PCR system 9600 (Applied Biosystem) using manufacturer's instructions. TaqMan gene expression assays for mouse GAPDH, FKBP51, and human FKBP51 were used. Briefly, 20- $\mu$ l reaction/tube contained TaqMan RT-PCR Mix (2×), TaqMan Gene Expression Assay (20×), TaqMan RT Enzyme Mix (40×), and Total RNA (50 ng) plus RNase-free water. The thermal cycling conditions were $48^{\circ} \mathrm{C}$ for 15 min (RT step) and for PCR, $95^{\circ} \mathrm{C}$ for $10 \mathrm{~min}, 40$ cycles $\left(95^{\circ} \mathrm{C}\right.$ for $15 \mathrm{~s}, 60^{\circ} \mathrm{C}$ for $\left.1 \mathrm{~min}\right)$.

Samples were assayed in a minimum of three replicates and the data were analyzed using the $\Delta \Delta \mathrm{C}_{\mathrm{T}}$ method (Livak and Schmittgen, 2001). The expression values were normalized to endogenous mouse Gapdh control values.

\section{Rotarod and open field}

Motor function was measured by rotarod and open field. For rotarod, three-month-old rTgFKBP5 ( $N=16$; eight males and eight females), WT ( $N=22 ; 10$ males and 12 females), and tTA control ( $N=20 ; 11$ males and nine females) mice were placed onto Rota-Rod apparatus (Stoelting; AugoBasile Apparatus) while the rod was rotating at four rotations per minute (rpm). The rod was accelerated at a steady rate to $40 \mathrm{rpm}$ over $300 \mathrm{~s}$. Latency to fall from the rod was measured. For analysis, both sexes were combined, since sex did not have a significant effect on result, see Extended Data Table 1-1 for additional statistical analysis.

For open field, three-month-old rTgFKBP5 ( $N=16$; eight males and eight females), WT ( $N=22 ; 10$ males and 12 females), and tTA control ( $N=20 ; 11$ males and nine females) mice were monitored for $15 \mathrm{~min}$ in an open field (Stoelting). One video for a female tTA mouse did not record properly, so our final tTA $N=19$. Activity was recorded and analyzed using ANY-maze video tracking software (Stoelting). For analysis, both sexes were combined, since sex did not have a significant effect on result, see Extended Data Table 1-1 for additional statistical analysis. 


\section{Tail suspension test (TST) and Porsolt forced swim test (FST)}

For TST and FST, three-month-old old rTgFKBP5 ( $N=$ 16; eight males and eight females), WT ( $N=22 ; 10$ males and 12 females), and tTA control $(N=20 ; 11$ males and nine females) mice were suspended form their tail for 6 min in a tail-suspension apparatus (Stoelting). Amount of time immobile was recorded. For FST, old rTgFKBP5 ( $N=$ 16; eight males and eight females), WT ( $N=22 ; 10$ males and 12 females), and tTA control $(N=20 ; 11$ males and nine females) mice were placed in $4 \mathrm{~L}$ clear, glass cylinders filled to $12 \mathrm{~cm}$ with room temperature water and allowed to swim for 6 min. Amount of time immobile was recorded. For analysis, both sexes were combined, since sex did not have a significant effect on result, see Extended Data Table 1-1 for additional statistical analysis.

\section{Sucrose preference test}

To measure pleasuring seeking behavior or lack thereof, we tested the mice using the sucrose preference test. For this task, individually housed three-month-old old rTgFKBP5 ( $N=16$; eight males and eight females), WT $(N=22 ; 10$ males and 12 females), and tTA control ( $N$ $=20 ; 11$ males and nine females) mice were given two water bottles, one filled with tap water and the other filled with $1 \%$ sucrose in tap water, which were switched in location after $24 \mathrm{~h}$ to help prevent a side preference bias. Following a 48-h habituation, all water was removed for $12 \mathrm{~h}$ during the whole dark cycle. Soon after the start of the light cycle, mice were again exposed to the two pre-weighed leak-proof water bottles side-by-side. The positioning of the bottles was randomly assigned across animals to prevent bottle location preference. The bottles were carefully switched in their location at $1 \mathrm{~h}$ in each cage and were removed from the cages after $2 \mathrm{~h}$ and weighed again. Sucrose preference was determined based on amount of sucrose water consumed compared to the total amount consumed from both bottles combined. Both sexes are shown separately in Extended data Fig. 3-1, since sex had a significant effect, see Extended Data Table 1-1 for additional statistical analysis.

\section{Morris water maze (MWM) and reversal}

rTgFKBP5 ( $N=10$; six males and four females), WT ( $N$ = 10; five males and fivefemales), and tTA control ( $N=$ 10; five males and five females) mice were trained to locate a hidden escape platform. Each mouse was given 4- to 60-s trials per day with a 1-min intertrial interval in a randomized quadrant. If the target platform was not found, the mice were led to the platform, where they remained for $15 \mathrm{~s}$. The training was completed over $4 \mathrm{~d}$, when the control group was able to find the platform by 10 $\mathrm{s}$. Twenty-four hours later, the hidden platform was removed for the probe test. Mice were placed in the pool in the quadrant opposite of where the target location and allowed to swim for $60 \mathrm{~s}$. The following day, the hidden platform was returned to the pool in the quadrant opposite to the initial training. Mice were retrained to locate this platform until the control group was able to identify the location by $10 \mathrm{~s}$. The next day, mice were subjected to another probe trial. Each day was recorded and analyzed using ANY-maze video tracking software. For analysis, both sexes were combined, since sex did not have a significant effect on result, see Extended Data Table 1-1 for additional statistical analysis.

\section{Electrophysiology recordings}

Acute ex vivo hippocampal brain slices were prepared for each of the electrophysiological experiments. Mice of either sex between the ages of 2- and 3.5-months were killed by rapid decapitation and brains were quickly removed and placed into oxygenated, ice-cold cutting solution ( $100 \mathrm{mM}$ sucrose, $60 \mathrm{mM} \mathrm{NaCl}, 3 \mathrm{mM} \mathrm{KCl}, 1.25 \mathrm{mM}$ $\mathrm{NaH}_{2} \mathrm{PO}_{4}, 28 \mathrm{mM} \mathrm{HNaCO}, 5 \mathrm{mM}$ D-glucose, $0.6 \mathrm{mM}$ ascorbate, $0.5 \mathrm{mM} \mathrm{CaCl}_{2}$, and $7 \mathrm{mM} \mathrm{MgCl}_{2}$ ). Tissue was then sectioned in ice-cold cutting solution with a depth of $400 \mu \mathrm{m}$ using a vibratome (Leica Biosystems) and hippocampi were carefully excised from the rest of the tissue. Hippocampal tissue was exposed to a 50:50 cutting and artificial CSF (ACSF) solution $(125 \mathrm{mM} \mathrm{NaCl}, 2.5 \mathrm{mM} \mathrm{KCl}$, $1.25 \mathrm{mM} \mathrm{NaH}_{2} \mathrm{PO}_{4}, 25 \mathrm{mM} \mathrm{HNaCO}_{3}, 25 \mathrm{mM}$ D-glucose, 2 $\mathrm{mM} \mathrm{CaCl}$, and $1 \mathrm{mM} \mathrm{MgCl}$ ) for $10 \mathrm{~min}$. Hippocampi were then allowed to recover in an interface chamber for $1 \mathrm{~h}$ in $30^{\circ} \mathrm{C}$ ACSF. Stimulating and recording electrodes were placed along the Schaffer collateral pathway in the CA3 and CA1, respectively. Slices were then stimulated for 5-10 $\mathrm{min}$, to establish a consistent response to voltage stimulus. Once a consistent response to a voltage stimulus was established, threshold voltage for evoking fEPSPs was determined and the voltage was increased incrementally every $0.5 \mathrm{mV}$ until the maximum amplitude of the fEPSP was reached [input-output (I-O) curve]. All other stimulation paradigms were induced at the same voltage, defined as $50 \%$ of the stimulus voltage used to produce the maximum fEPSP amplitude, for each individual slice. This method ensures that recordings made following low-frequency stimulation (LFS) or multiple trains of high-frequency stimulation (HFS) can be compared within groups. Slices were included in analysis if baseline was consistently maintained, as determined by a $10 \%$ or less variation in signal.

\section{Long-term potentiation (LTP)}

Following a 20-min baseline recording, slices from either sex were stimulated by either one-train [rTgFKBP5 ( $N$ $=5 ; 18$ slices), WT ( $N=6 ; 29$ slices), and tTA ( $N=5 ; 22$ slices)] or four-trains [rTgFKBP5 $(N=7 ; 16$ slices), WT ( $N$ $=6 ; 23$ slices), and tTA ( $N=7 ; 26$ slices)] of $100-\mathrm{Hz}$ stimulation for $1 \mathrm{~s}$ with a pulse width of $0.100 \mathrm{~ms}$. Evoked potentiation (fEPSPs), as measured by the initial slope normalized to the averaged baseline slope of each slice, was recorded for 60 min following HFS.

\section{I-O}

I-O was recorded in rTgFKBP5 ( $N=15 ; 65$ slices), WT ( $N=15 ; 62$ slices), and tTA ( $N=19 ; 77$ slices) slices from either sex to establish threshold voltage for evoking a fEPSP response. This was achieved by increasing voltage in $0.5 \mathrm{mV}$ increments, until maximum amplitude of the fEPSP was reached. Presynaptic I-O was measured by the amplitude of the fiber volley, as a direct read out of depolarization of the presynaptic terminal and the post- 
synaptic I-O was measured by the initial slope of the fEPSP wave form (Zhang et al., 2009).

\section{Paired-pulse facilitation (PPF)}

As a measurement of short-term plasticity, PPF was recorded in rTgFKBP5 ( $N=31$ mice; 175 slices), WT ( $N=$ 33; 198 slices), and tTA ( $N=30 ; 181$ slices) slices from either sex using sequential pulses at $50 \%$ of the maximum fEPSP. Recordings were performed over $15-300 \mathrm{~ms}$ of interpulse intervals. The data are derived from comparing the slope of the fEPSPs at baseline and following the sequential pulse at $20 \mathrm{~ms}$ intervals.

\section{Long-term depression (LTD)}

Acute ex vivo slices were prepared as described above, following a 20-min baseline recording, slices from either sex rTgFKBP5 ( $N=9$; 21 slices), WT ( $N=9$; 23 slices), and tTA control ( $N=10$; 31 slices) mice were stimulated by 900 pulses of LFS $(3 \mathrm{~Hz})$ to induce LTD. Evoked depotentiation was recorded, as calculated by the slope of the initial fEPSPs normalized to baseline, for $60 \mathrm{~min}$ following stimulation.

\section{Acute ex vivo drug dumps AMPA receptor internalization assays}

Slices from male rTgFKBP5 or control (WT and tTA combined) mice were prepared as described above for electrophysiological recordings. Following sectioning, slices were allowed to recover for $1 \mathrm{~h}$ with Leupeptin, hippocampi were rapidly chilled in ice cold ASCF. Tissue was incubated with $1 \mathrm{mg} / \mathrm{ml}$ Sulfo-NHS-SS-biotin for 30 min on a rocker at $4^{\circ} \mathrm{C}$. Hippocampi were immediately washed with ice-cold ACSF and placed directly into 20 $\mu \mathrm{M}$ NMDA in $30^{\circ} \mathrm{C}$ ACSF for $5 \mathrm{~min}$, except for the untreated samples, which were kept in ice-cold ACSF. Hippocampi, except for the 0-min time point which was placed directly into ice cold ACSF, were then transferred to $30^{\circ} \mathrm{C} \mathrm{ACSF}$ and incubated for the indicated times. After each time point elapsed, hippocampi were removed from the solution and placed in ice-cold ACSF and maintained at $4^{\circ} \mathrm{C}$ for the remainder of the experiment. The biotin remaining on the surface was then cleaved using ice-cold glutathione cleavage solution ( $50 \mathrm{mM}$ glutathione, $75 \mathrm{mM}$ $\mathrm{NaCl}, 10 \mathrm{mM}$ EDTA, and 1\% BSA; pH 8.75) over two 15-min incubations. The hippocampi were briefly placed into ice-cold glutathione neutralization solution $(50 \mathrm{mM}$ iodoacetamide in DPBS, pH7.4). Following two ice-cold ACSF washes, hippocampi were lysed in 200- $\mu$ l RIPA buffer supplemented with phosphatase inhibitors, protease inhibitors for tissue, and PMSF by sonication. Protein concentrations were determined by $\mathrm{BCA}$, and equal amounts per sample were used for streptavidin coimmunoprecipitation described below.

Streptavidin immunoprecipitation was performed overnight on a rotator using $500 \mu \mathrm{g}$ of each lysate with $100 \mu \mathrm{l}$ of washed Streptavidin UltraLink Plus agarose beads (Pierce). The next day, all unbound protein was washed off and the resin was boiled for 5 min in Laemmli buffer with $5 \% \quad \beta$-mercaptoethanol. The resulting sample was then centrifuged to pellet the beads and the supernatant was then run on SDS-PAGE gels and processed by Western blotting.

\section{Transfection}

HEK293T cells (ATCC catalog \#CRL-3216, RRID: CVCL_0063) were transfected using Lipofectamine 2000 (Thermo Scientific), as recommended by the manufacturer, with FKBP5 TRE or control plasmid with or without tTA plasmid for $48 \mathrm{~h}$. Cells were then washed with PBS and harvested in RIPA buffer supplemented with protease and phosphatase inhibitors. Following sonication, cells were incubated on ice for $15 \mathrm{~min}$, cell debris was pelleted by centrifugation at $13,000 \times g$ for $15 \mathrm{~min}$, and protein in the supernatant was determined by BCA and analyzed by Western blotting.

HEK293T cells were transfected using Lipofectamine 2000 with GluR1 and FKBP51 or control plasmid for $48 \mathrm{~h}$. AMPA (100 $\mu \mathrm{M}, 10 \mathrm{~min})$ was applied just before harvest. Cells were then washed with PBS and harvested in RIPA buffer supplemented with protease and phosphatase inhibitors. Following sonication, cells were incubated on ice and processed as described below.

\section{GluR1 co-immunoprecipitation}

Male rTgFKBP5 and control mice (WT and tTA combined) were overdosed with pentobarbital solution and transcardially perfused with $0.9 \%$ saline solution; brains were rapidly removed. The hippocampi were carefully excised and immediately put into ice-cold co-immunoprecipitation buffer $(50 \mathrm{mM}$ Tris- $\mathrm{HCl}, 1 \%$ Triton X-100, $1 \mathrm{mM}$ EDTA, and $150 \mathrm{mM} \mathrm{NaCl}$ ) and sonicated on ice. Tissue lysates were pelleted at 10,000 RCF for $5 \mathrm{~min}$, and the remaining supernatant was pre-cleared with unlabeled-mouse IgG (SouthernBiotech catalog \#010701, RRID:AB_2732898) and Protein A Dynabeads (Life Technologies) for $90 \mathrm{~min}$. Following pre-clearing and protein estimation, GluR1 antibody was added to $2 \mathrm{mg}$ of protein per sample and rotated overnight at $4^{\circ} \mathrm{C}$. Rabbit IgG unlabeled (SouthernBiotech catalog \#0111-01, RRID: AB_2732899) was used for IgG control sample. GluR1/ control antibody and bound proteins were then isolated using $50 \mu \mathrm{l}$ of Protein A Dynabeads. Following four washes, the beads/antibody were disassociated from bound proteins by a 5 -min incubation at $100^{\circ} \mathrm{C}$ in $35 \mu \mathrm{l}$ of $2 \times$ Laemmli buffer with $5 \% \beta$-mercaptoethanol. Beads were isolated using a magnet and the resulting protein sample was processed by Western blotting.

Whole homogenate lysates from HEK293T cells transfected pCl-SEP-GluR1 was a gift from Robert Malinow (Addgene plasmid \# 24000 ; RRID:Addgene_24000, Kopec et al., 2006) and either pCMV6 empty vector or pCMV6 FKBP5 $\pm 100 \mu \mathrm{M}$ AMPA treatment were precleared with Protein A Dynabeads. Co-immunoprecipitation was performed using $2 \mathrm{mg}$ of precleared lysate incubated with either rabbit IgG UNLB (Southern Biotech) or rabbit $\alpha$-C-GluR1 (Millipore catalog \#AB1504, RRID: $A B$ 2113602) antibody, respectively, overnight on a rocker at $4^{\circ} \mathrm{C}$. A total of $50 \mu \mathrm{l}$ of Protein A magnetic Dynabeads was added to each tube and this mixture was incubated on a rocker at $4^{\circ} \mathrm{C}$ for $4 \mathrm{~h}$. Following bead conjugation, bound proteins were isolated using a magnet 
and washed four times. Beads and bound proteins were then disassociated as described above. Tubes were placed on a magnetic strip, and the whole supernatant was processed by Western blotting.

\section{Statistical analysis}

Data were investigated for normality using a D'Agostino and Pearson test and data in graphs and text are presents as the mean \pm SEM, unless otherwise stated; $p$ values below 0.05 were considered significant. All analysis was performed using GraphPad Prism 5 and is summarized in detail in Table 1. Analysis for sex differences in behavioral tasks is included in Extended Data Table 1-1. To compare two groups, an unpaired two-tailed Student's $t$ test was used for parametric data and the Mann-Whitney test was used for non-parametric analysis. Groups larger than two were evaluated by one-way or two-way ANOVA, as appropriate with genotype and age/quadrant/time as factors. $F$ values are reported as decreases of freedom between groups and within groups. Significance is shown in the figures for results where rTgFKBP5 mice are significantly different from control littermates.

\section{Results}

\section{Generation of the rTgFKBP5 mice and the characterization of FKBP5 expression}

In an effort to understand the role of FKBP5 in learning and memory (Binder et al., 2008; Tyrka et al., 2015), we generated novel transgenic mice to overexpress FKBP51 throughout the forebrain. These mice were generated by crossing mice expressing the tetracycline (Tet)-Off transactivator (tTA) driven by a CaMKIl $\alpha$ promoter $(\mathrm{CaMKIl} \alpha-$ tTA) with our novel transgenic mice expressing human FKBP5 under control of a Tet-responsive element, yielding bigenic offspring which included: WT, tTA, FKBP5, and mice positive for both tTA and FKBP5, deemed rTgFKBP5. It has previously been shown that this bigenic strategy leads to robust forebrain expression, which starts at approximately one week postnatal and progressively increases to adult levels by three weeks postnatal due to the activity of the CaMKIl $\alpha$ promoter (Kelly and Vernon, 1985; Mayford et al., 1996; Wei et al., 2004; for details of transgenic construction and validation, see Fig. $1 A-C$ ). Quantitative real-time PCR revealed that human FKBP5 expression was $\sim 12$-fold higher in adult $\mathrm{rTgFKBP5}$ mice relative to mouse Fkbp5 mRNA in WT littermates (Fig. 2A). Mouse Fkbp5 levels were unaffected by the exogenous transgene, suggesting an absence of feedback regulation. Western blot analysis of hippocampal lysates from rTgFKBP5 mice revealed dramatically higher levels of FKBP51 protein compared to WT, FKBP5 single, and tTA littermates (Fig. $2 B$ ). In fact, $50 \mu \mathrm{g}$ of protein from the hippocampus of WT, tTA, and FKBP5-singles was similarly immunoreactive to anti-FKBP51 antibody as $10 \mu \mathrm{g}$ of protein from the bigenic mice (Fig. $2 C$ ). Elevated human FKBP51 was observed throughout the corticolimbic system including the hippocampus, striatum, and cortices by both immunohistochemistry (Fig. $2 D, E$ ) and Western blotting (Fig. 2F,G), consistent with the expression pattern of the CaMKII $\alpha$-tTa (Wang et al., 2013). To understand the effects of this FKBP51 overexpression, we analyzed the rTgFKBP5 mouse model for general phenotypes, motor ability, and depression-like behavior as well as learning and memory compared to both the WT and tTA control littermates.

\section{rTgFKBP5 mice have normal body weight, motor function, and unchanged depression-like and anxiety-like phenotypes but display reduced pleasure-seeking behavior}

The overexpression of FKBP51 in mice did not lead to any alteration in gross body weight in rTgFKBP5 mice compared to littermate controls (Fig. 3A). rTgFKBP5 mice also displayed no significant change in rotarod ability or total distance traveled in the open field test compared to controls, indicating FKBP51 did not alter locomotor function (Fig. 3B,C). rTgFKBP5 mice also spent similar time in the center zone compared to controls (Fig. $3 D$ ), suggesting general anxiety was unaffected (Bailey and Crawley, 2009). Since mice lacking FKBP51 have been shown to be protected from depression-like behaviors (O'Leary et al., 2011; Touma et al., 2011), we investigated whether the inverse was true in mice overexpressing FKBP51. Contrary to what we expected, we found that immobility times in the Porsolt FST and TST were unchanged from littermate controls (Fig. 3E,F). However, when exposed to the reward-based sucrose presence test, rTgFKBP5 mice consumed less sucrose-supplemented water than the tTA control counterparts in the reward-based sucrose preference test (Fig. 3G), suggesting increased anhedonia (Strekalova et al., 2011). In fact, they showed equal preference to the water-only and sucrose containing bottles. Interestingly, humans suffering from depression display decreased reward-seeking behavior that can be rescued by antidepressants (Wichers et al., 2009). Taken together, these findings demonstrate that corticolimbic FKBP5 expression does not affect gross body weight or motor function, while having a modest impact HPA axis function, feedback and associated phenotypes, at least in the absence of environmental factors such as stress.

\section{rTgFKBP5 mice have slowed spatial reversal learning and impaired cognitive flexibility}

Next, we sought to determine the consequences of increased FKBP51 levels on cognitive function. Using the MWM, which is a spatial learning and memory task that has been shown to be hippocampal-dependent, we found that $r$ TgFKBP5 mice trained to the location of the escape platform similarly to their control (WT and tTA) littermates (Fig. $4 A$ ), and all genotypes of mice were able to recall the location quadrant of the escape platform in the probe trial (Fig. 4B). However, when the location of the escape platform was moved to the reversed quadrant, rTgFKBP5 mice had significantly impaired escape latency during the training days (Fig. $4 C$ ), suggesting a deficit in re-training and re-acquisition, and, when tested by the reversal probe trial, rTgFKBP5 mice were unable to identify the target quadrant significantly from any other quadrant (Fig. $4 D$ ). This was unlike both control groups, which showed significant preference for the new target quadrant, as 
Table 1. Summary of statistical analyses

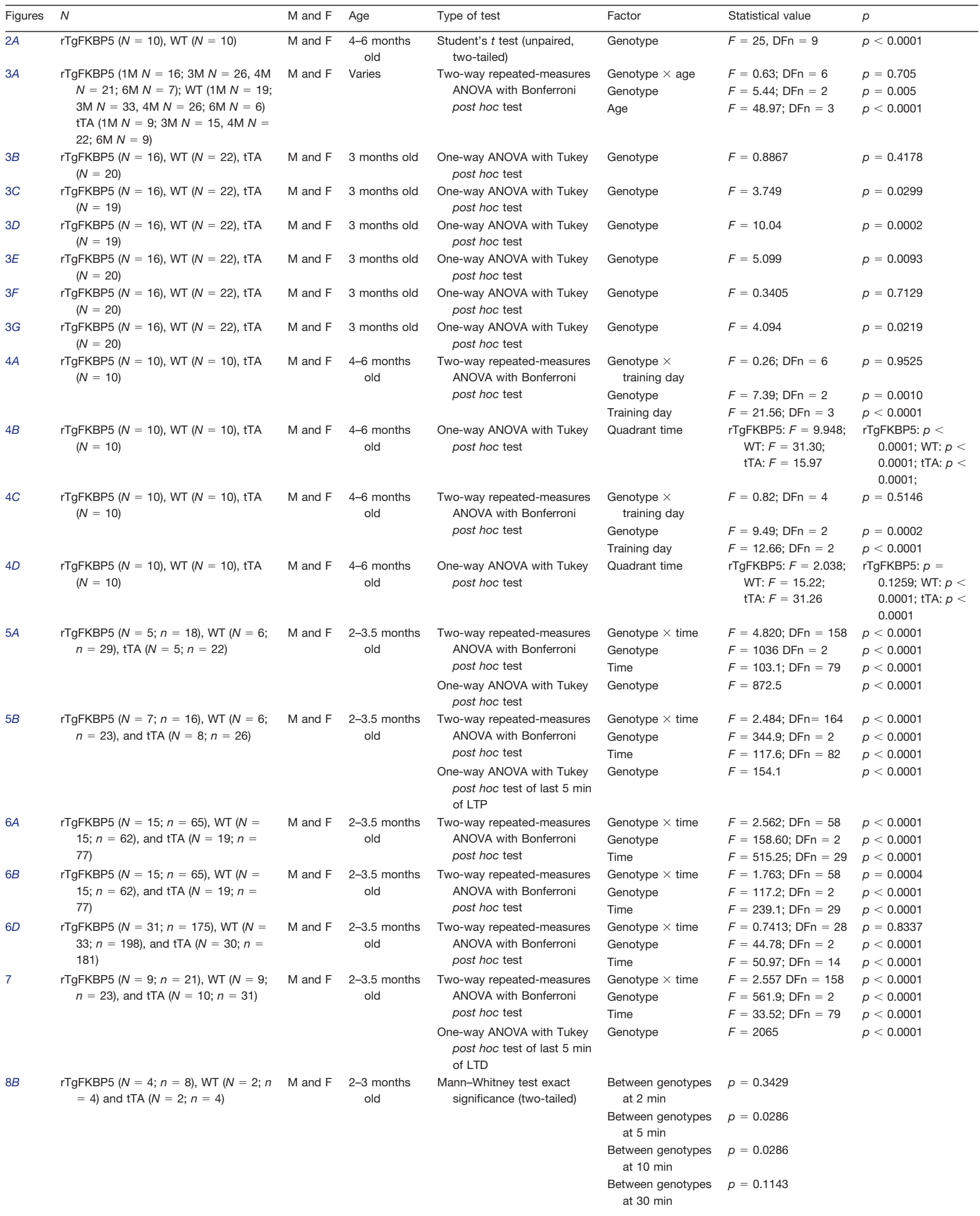


A
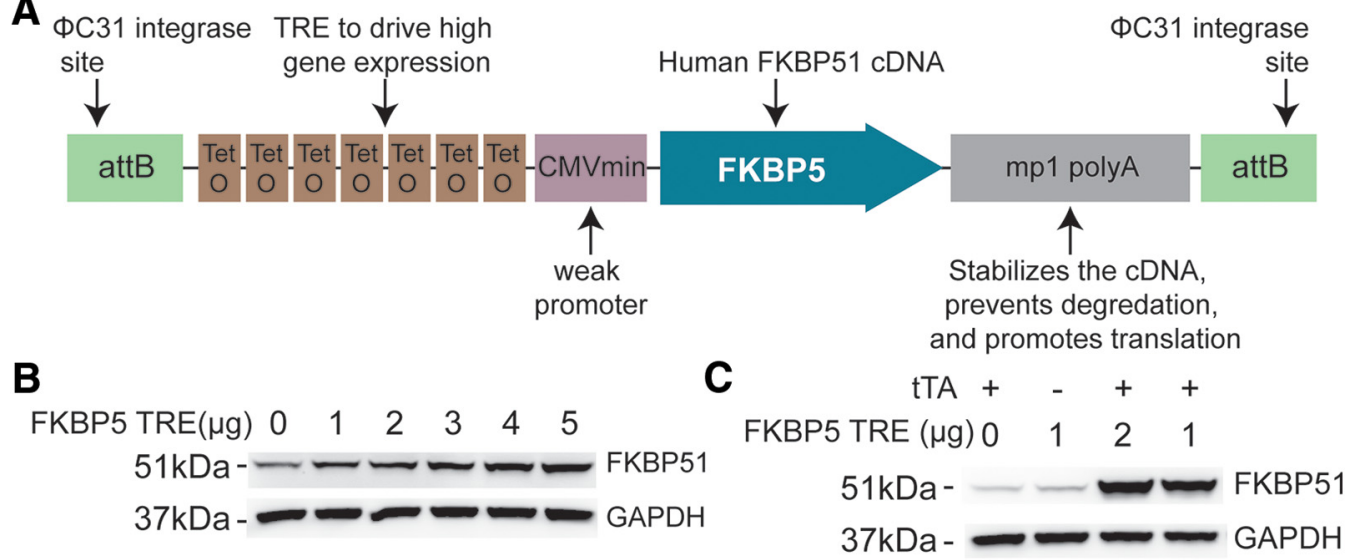

Figure 1. Detailed schematic and validation of the FKBP5 TRE transgene. $\boldsymbol{A}$, To allow for site-directed, single copy insertion into the mouse genome in chromosome 11, the transgenic construct contained flanking attB sites via a PhiC31 integrase. The downstream Mp1 poly A tail will help maintain stable expression. To drive high expression, the transgenic construct included a tetracycline-response element (TRE) promoter made of seven repeats of the tetracycline operators used to drive high expression of the singly inserted FKBP5 gene in the presence of the tTA, and a weak minimal CMV promoter which produces low basal expression. $\boldsymbol{B}$, Western blotting from HEK293T cells transfected with increasing amounts of FKBP5 TRE plasmid, as indicated, for 48 h. C, HEK293T cells were transfected with the indicated amounts of FKBP5 TRE and tTA plasmid, to ensure the tTA would drive high FKBP51 expression.

expected. Together, these data suggest that FKBP51 overexpression impaired spatial inhibitory learning.

\section{Overexpression of FKBP5 modestly enhances hippocampal LTP}

Hippocampal LTP is a well-known cellular correlate of memory formation (Luscher and Malenka, 2012). We used a HFS protocol to induce LTP in this model. Using a single $100-\mathrm{Hz}$ stimulation, LTP was modestly, but significantly, enhanced and maintained in hippocampal slice cultures from rTgFKBP5 mice compared to both WT and tTA control animals (Fig. 5A), suggesting an increase in synaptic strength in rTgFKBP5 mice through AMPA receptor modulation (Dong et al., 2013). While enhanced LTP is also a phenotype of the tTA mice (Han et al., 2012), the maintenance of LTP in rTgFKBP5 mice was still significantly greater than ITA mice. When we exposed slices in a parallel experiment to four trains of $100-\mathrm{Hz}$ stimulations, we found that the modest LTP enhancement over the tTA controls was no longer detected using this stimulation protocol (Fig. 5B). To determine the contribution of the presynapse and postsynapse, we analyzed the ratio of the input stimulus to evoke output activity. This I-O revealed that both the fiber volley and the slope of the EPSP (fEPSP) were significantly higher following the same stimulation intensity in rTgFKBP5 mice compared to littermate controls (Fig. $6 A-C$ ). This suggests that FKBP51 may be altering both pre- and post- synaptic signaling. PPF was unchanged in rTgFKBP5 mice from controls (Fig. 6D), suggesting that these effects are not due to calcium-mediated differences or short-term synaptic plasticity (Zucker and Regehr, 2002; Han et al., 2012). Collectively, these electrophysiology data suggest that hippocampal FKBP51 increases can promote excitability of neurons, which implicates a role in the regulation of AMPA receptors.

\section{Overexpression of FKBP5 impairs hippocampal long- term depression (LTD) by accelerating AMPA receptor recycling}

To further examine the possibility of AMPA receptor regulation by FKBP51, LFS-induced LTD was performed. Compared to control littermates, rTgFKBP5 mice displayed significantly impaired LTD (Fig. 7), in fact, their slopes returned to baseline levels around 10 min into the recording. Together, this provides additional evidence that AMPA receptor activation or localization to the synaptic membrane was altered in mice overexpressing FKBP51 (Dong et al., 2013).

Since GluR1-type AMPA receptor endocytosis has been correlated with LTD (Lee et al., 2010), we next examined whether GluR1 receptor recycling was altered in the hippocampus of rTgFKBP5 mice. Once internalized these receptors can have two fates, they can be degraded by macroautophagy or be recycled back to the membrane surface (Ehlers, 2000). Using ex vivo hippocampal slices from rTgFKBP5 and control mice, we biotinylated all of the surface receptors and then stimulated internalization by a chemical LTD protocol (Lee et al., 1998). Following LTD stimulation, slices were incubated for up to $30 \mathrm{~min}$, as indicated. Once the designated time has passed extracellular biotin was cleaved and the internalized receptors were analyzed by immunoprecipitation (Fig. $8 A$ ). Quantification of the internalized receptors (Fig. $8 B$ ) revealed marked differences in the maintenance of internalized GluR1 receptors in rTgFKBP5 mice compared to littermates following chemically-induced LTD. In line with our electrophysiology results, rTgFKBP5 mice were unable to maintain the internalized GluR1 receptor pool as well as their control littermates. These assays were performed in the presence of leupeptin, a macroautophagy inhibitor, to preserve the internalized receptors that are not fated for recycling back to the surface. 


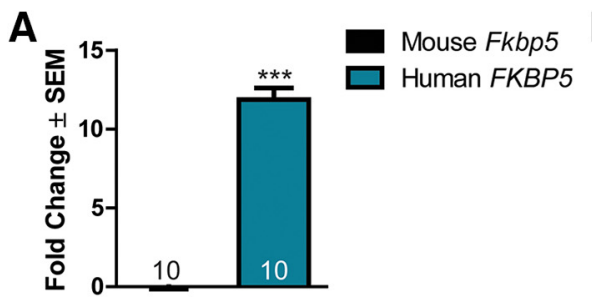

B
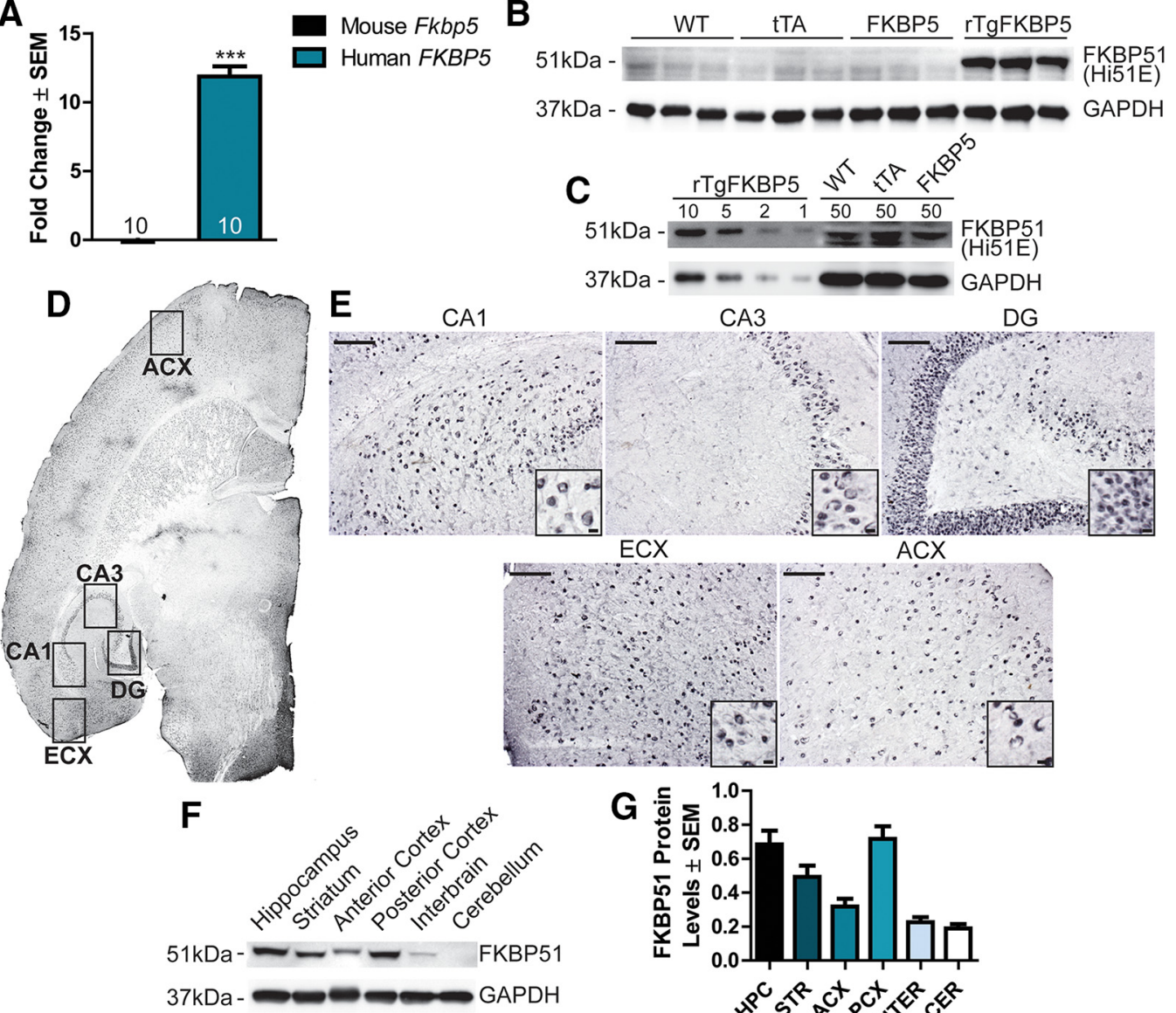

$37 \mathrm{kDa}-0 \mathrm{GAPDH}$

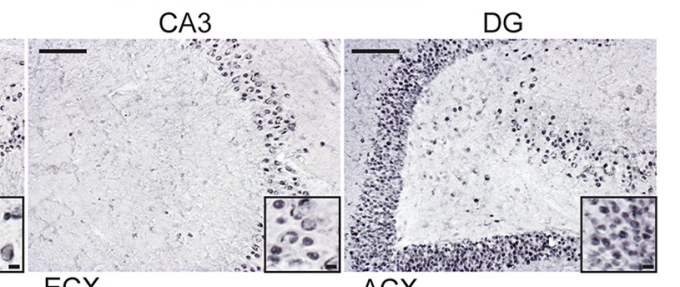

ECX ACX
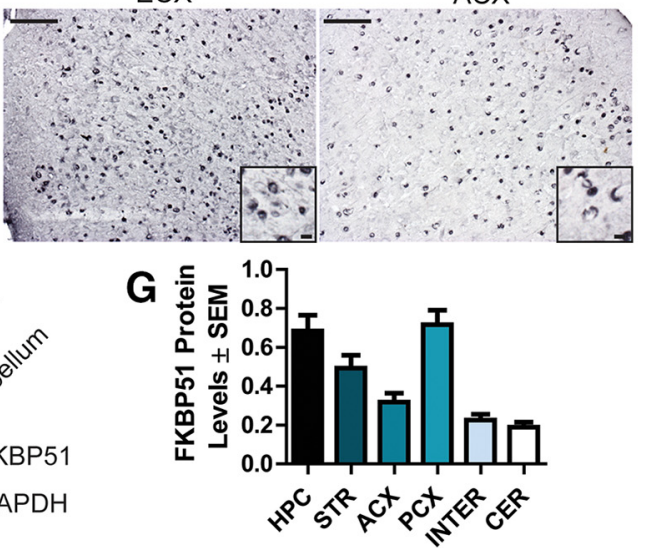

Figure 2. FKBP51 expression and distribution in rTgFKBP5 mice. $\boldsymbol{A}$, Expression of human and mouse FKBP5 in rTgFKBP5 mice expressed as fold change \pm SEM compared to WT mice using qPCR; $* * * p<0.001$ by $t$ test $(N=10)$ with three technical replicates. $\boldsymbol{B}$, Western blotting showing FKBP51 levels in the hippocampus from rTgFKBP5, WT, FKBP5, and tTA mice. $\boldsymbol{C}$, Western blotting showing levels of FKBP51 levels in the rTgFKBP5 hippocampus from 1 to $10 \mu \mathrm{g}$ of protein loaded compared to $50 \mu \mathrm{g}$ of protein from WT or FKBP51 mice. GAPDH levels are shown to confirm protein load. See Extended Data Figure 2-1 for more information on the antibody. $\boldsymbol{D}, 20 \times$ images of anti-FKBP51 staining from rTgFKBP5 mice. The entorhinal cortex (ECX), anterior cortex (ACX), CA1, CA3, and dentate gyrus (DG) are labeled. $\boldsymbol{E}, 20 \times$ images of anti-FKBP51 staining from rTgFKBP5 mice in the CA1, CA3, DG, ECX, and ACX. Scale bar $=100 \mu \mathrm{m} ; 10 \mu \mathrm{m}$ (inset). $\boldsymbol{F}$, Western blotting showing FKBP51 levels in the hippocampus, striatum, ACX, posterior cortex (PCX), interbrain, thalamus and hypothalamus, and cerebellum of a rTgFKBP5 mouse. G, Quantitation of FKBP51 proteins levels throughout the hippocampus (HPC), striatum (STR), ACX, PCX, interbrain, thalamus and hypothalamus (INTER), and cerebellum (CER), of rTgFKBP5 mice from multiple exposures.

Thus, since rTgFKBP5 mice had a rapid loss of internalized GluR1 receptors compared to control mice, these findings indicate that FKBP51 promotes recycling of AMPA receptors back to the membrane.

\section{FKBP51 enhances GluR1-type AMPA receptor binding to Hsp90}

It was previously shown that Hsp90 can regulate AMPA receptor cycling through an interaction with the tetratricopeptide repeat (TPR) domain (Gerges et al., 2004). Therefore, we speculated that since FKBP51 contains a TPR domain and is a known Hsp90 co-chaperone, it was regulating GluR1-type AMPA receptor trafficking through its association with Hsp90. Indeed, more Hsp90/GluR1 complexes were present in hippocampal lysates from rTgFKBP5 mice compared to littermates (Fig. 8C). We corroborated these results in a HEK293T cell model, which was transfected with GluR1 and FKBP51 as indi- cated. Co-immunoprecipitation revealed that GluR1 can interact with both FKBP51 and Hsp90 (Fig. 8D) with and without AMPA treatment to stimulate GluR1 internalization (Ehlers, 2000). Moreover, increased FKBP51 levels enhanced the association of Hsp90 with GluR1, suggesting the high levels of FKBP51 can stimulate AMPA receptor recycling by increasing the interaction between Hsp90 and GluR1 impacting synaptic plasticity.

\section{Discussion}

FKBP5 is a risk factor in a growing number of affective disorders with diverse symptoms, particularly those arising from childhood trauma (Zannas et al., 2016). Our results identify a previously unknown function for FKBP51 in inhibitory learning and bidirectional synaptic plasticity that could underlie some of the phenotypes observed in patients. In this way, the rTgFKBP5 mouse model could prove a valuable tool for preclinical investigation of ther- 

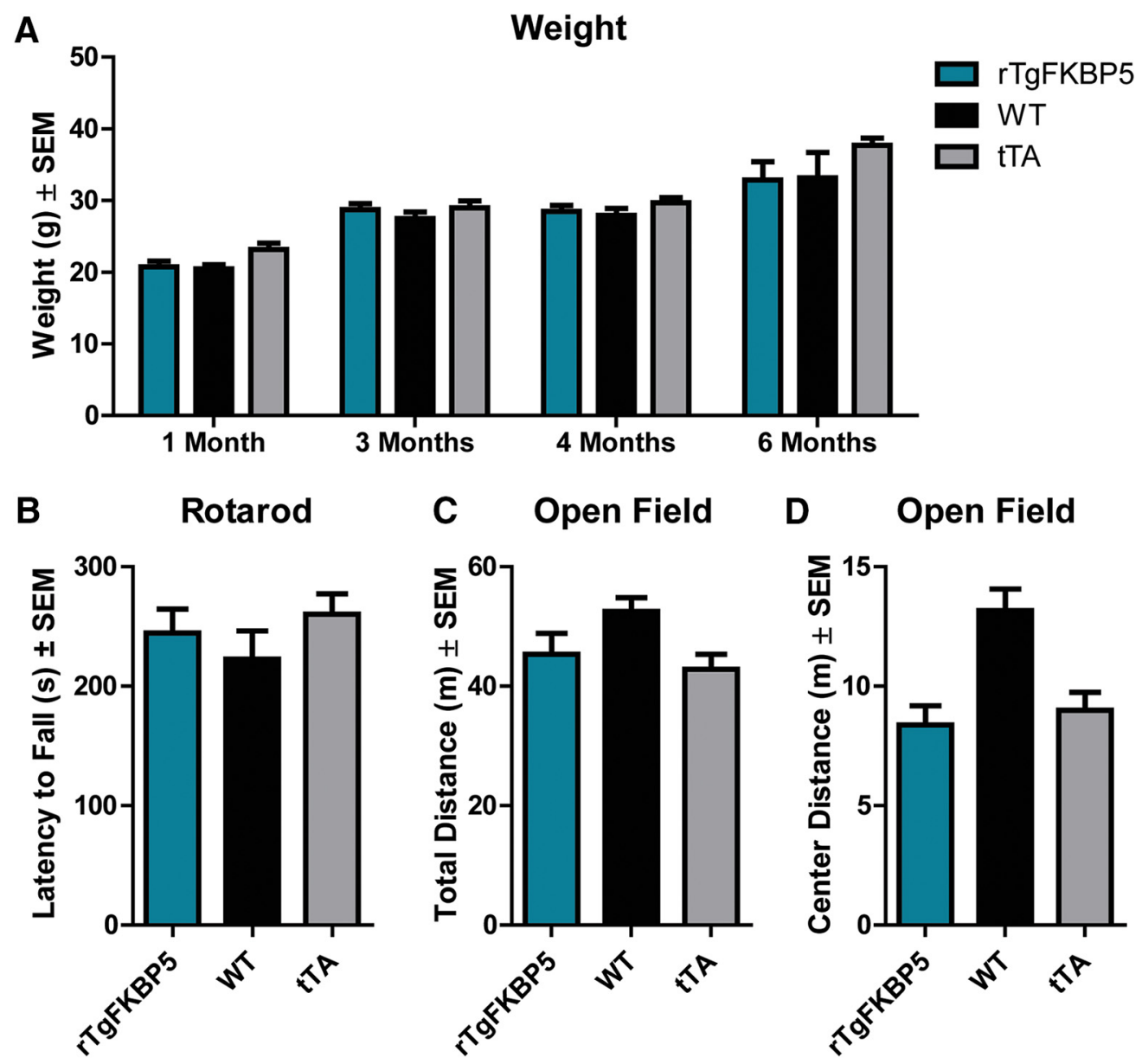

C Open Field

D Open Field
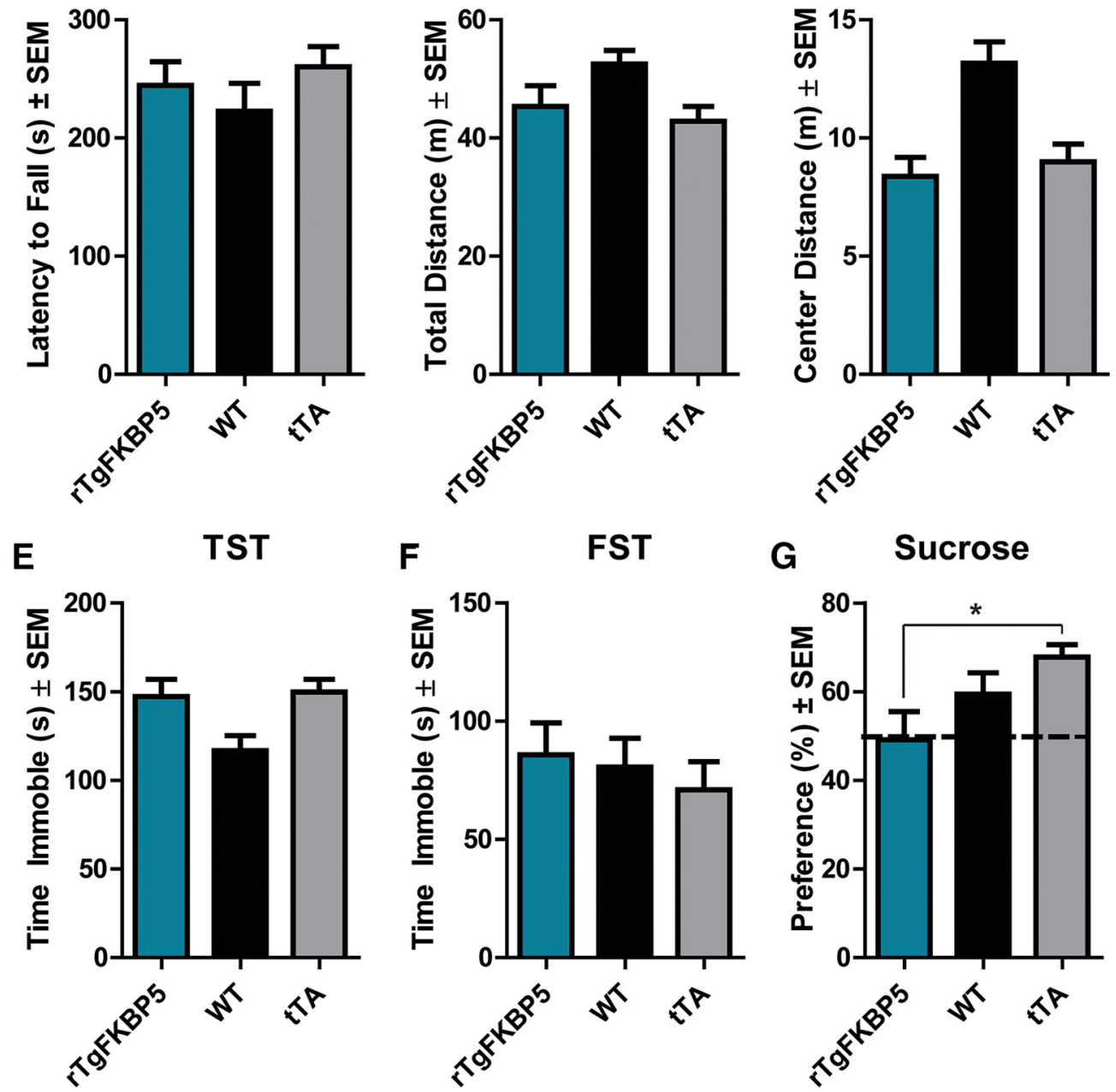

Figure 3. FKBP51 overexpression does not alter basal weight, motor ability, general anxiety, or depression-like behavior but has modest effects on pleasure seeking behavior. $\boldsymbol{A}$, Whole body weight for rTgFKBP5, WT, and tTA mice was recorded at the indicated time points $N \geq 7$ /genotype at each time point. $B$, Time on the rotarod apparatus in rTgFKBP5 $(N=16)$, WT $(N=22)$, and tTA $(N$ $=20)$ mice. Total distance traveled $(\boldsymbol{C})$ and distance traveled $(\boldsymbol{D})$ in the center in the open field task was measured for $\mathrm{rTgFKBP5}(N$ $=16)$, WT $(N=22)$, and tTA $(N=19)$ mice. Total immobility time was recorded over $360 \mathrm{~s}$ of the $(\boldsymbol{E})$ TST and $(\boldsymbol{F})$ FST. $\boldsymbol{G}$, Sucrose preference was measured in rTgFKBP5 $(N=16)$, WT $(N=22)$, and tTA $(N=20)$ mice. Consumption was measured by the difference in the weight of bottles filled with sucrose water versus tap water. Sucrose preference percentage \pm SEM was determined by the amount (g) of sucrose water consumed versus the amount of total water consumed over the 2-h task. See Extended Data Figure 3-1 for sex differences. $* p=0.0219$. 
A

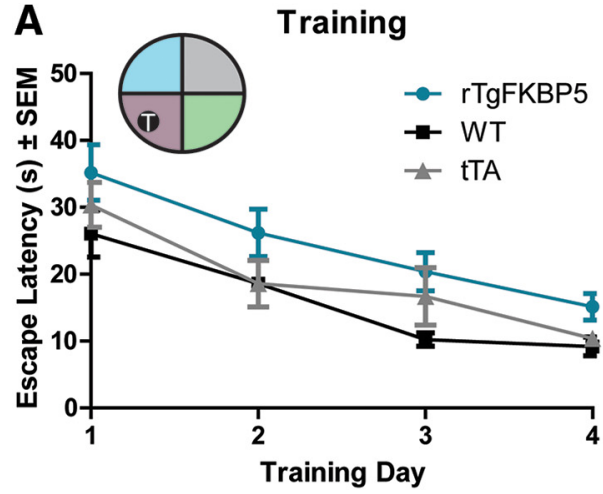

C

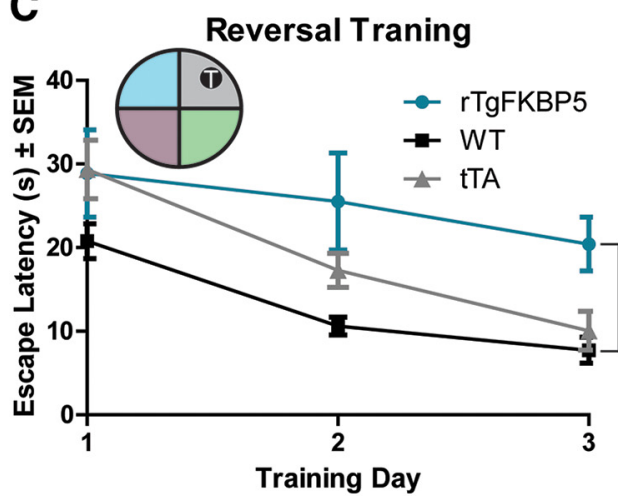

B

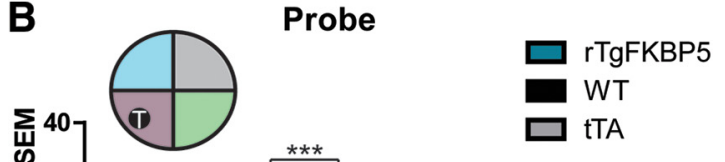

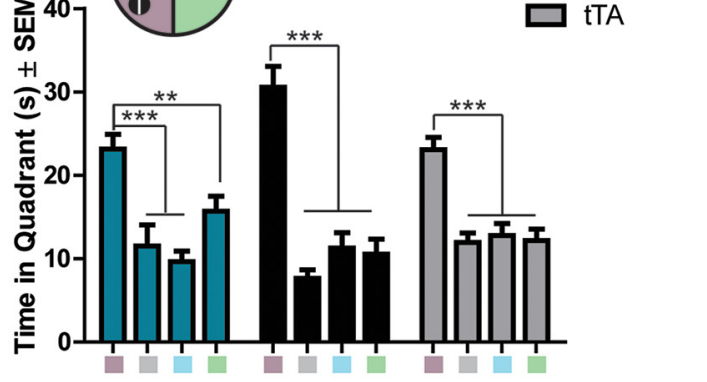

D
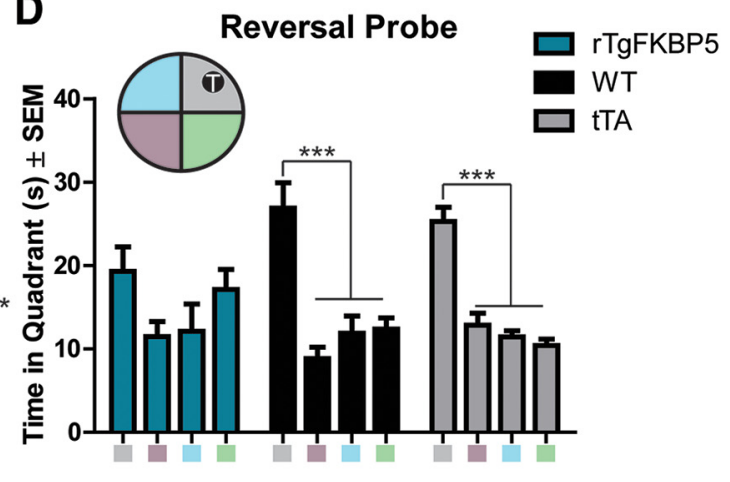

Figure 4. $r T g F K B P 5$ exhibit reversal deficits MWM reversal learning and memory. $\boldsymbol{A}$, Escape latencies (s) \pm SEM from rTgFKBP5, WT, and tTA control mice $(N=10 /$ genotype) over $4 \mathrm{~d}$ of training in the MWM behavioral task. Two-way ANOVA of entire training. The probe trial \pm SEM from $(B)$ rTgFKBP5, WT, and tTA mice $24 \mathrm{~h}$ after the last training session; $* * * p<0.001, * * p<0.01$ by one-way ANOVA. C, Escape latencies (s) \pm SEM of $r T g F K B P 5, W T$, and tTA mice ( $N=10 /$ genotype) trained to find an escape platform in the opposite quadrant of the initial MWM; $* * * p<0.001$ by two-way ANOVA. $\boldsymbol{D}$, The reversal probe trial \pm SEM from rTgFKBP5, WT, and tTA mice; $* * * p<0.001$ by one-way ANOVA.

apies for this group of disorders. Using this transgenic model, we have found that FKBP51 contributes to the fate decisions of internalized GluR1-type AMPA receptors by increasing the association with Hsp90. This interaction specifically accelerates the recycling rate of GluR1 receptors to the synaptic membrane during synaptic activity (Fig. 9). This is the first time that FKBP51 has been shown to regulate GluR1-type AMPA receptors and could explain how elevations in FKBP5 relate to diverse phenotypes in psychiatric disorders and other diseases.

This work highlights a novel way that FKBP51 can regulate synaptic plasticity and membrane receptor trafficking. We found that spatial reversal learning was significantly impaired in rTgFKBP5 mice as was LTD, which has been shown to be a mediator of reversal learning (Dong et al., 2013). At the same time, rTgFKBP5 mice had an enhancement of LTP and an increase in neuronal excitability, but no cognitive improvements were measured. It is possible that the age difference in the mice used for behavior (four to six months old) compared to the mice used for electrophysiology (2-3.5 months old) could have an impact on the dynamics of learning and memory, although we do not expect there to be significant differences in learning and memory over this timeframe, it is possible. However, previous studies have demonstrated that LTP can be enhanced independently of performance on cognitive tasks (Schmidt et al., 2011). Interestingly, it has also been demonstrated that LTP can inhibit LTD, and that this is through the glycogen synthase kinase (GSK)-3 $\beta$ and AKT (also known as protein kinase B) pathways (Peineau et al., 2007), a pathway that FKBP51 has been shown to directly regulate through pleckstrin homology domain leucine-rich repeat protein phosphatase (PHLPP; Wang, 2011; Gassen et al., 2014). Potentially FKBP51 is altering LTD and learning and memory through regulation of this pathway. In addition, FKBP51 can increase autophagic activity (Gassen et al., 2015) and, thus, could regulate synaptic plasticity by altering the turnover of many components including AMPA receptors. Additional studies are needed to better understand the crosstalk between FKBP51 and synaptic plasticity.

Our findings also highlight a novel role for FKBP5 in age-related cognitive decline and psychiatric illness, since FKBP5 levels progressively increase in these disorders (Blair et al., 2013; Sabbagh et al., 2014; Zheng et al., 2016). Reversal learning and cognitive flexibility are negatively impacted by aging (Glisky, 2007; Gajewski et al., 2010; Schoenfeld et al., 2014), a phenotype that was observed in the rTgFKBP5 mouse model (Fig. 4A-D). Moreover, LTD impairments have been reported in aged animals (Lee et al., 2005; Potier et al., 2010), consistent with our model (Fig. 7). Perhaps FKBP51 contributes to PTSD symptoms by disrupting the ability to extinguish memories, therefore allowing individuals to better main- 
A

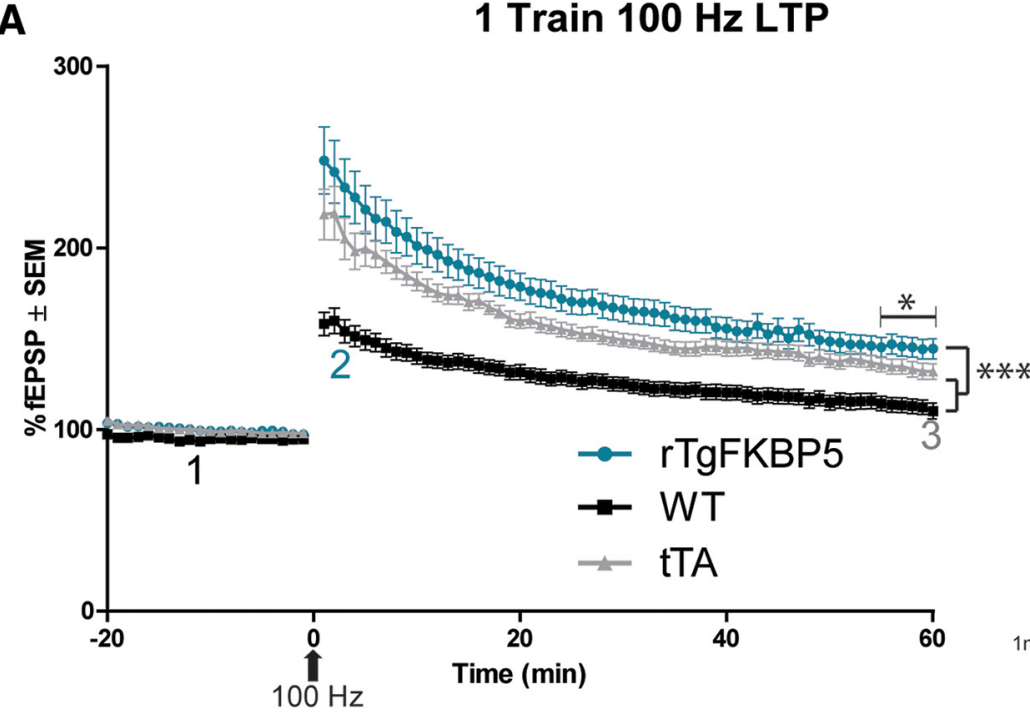

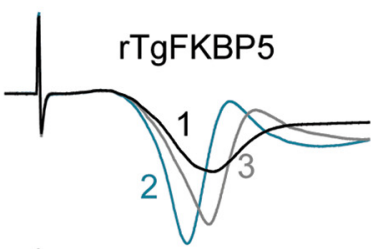

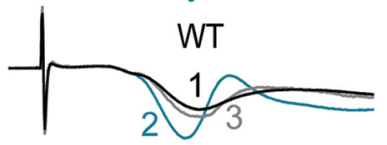

$\mathrm{mVL}$

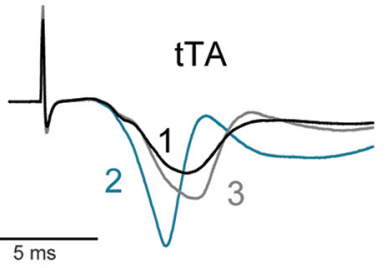

B

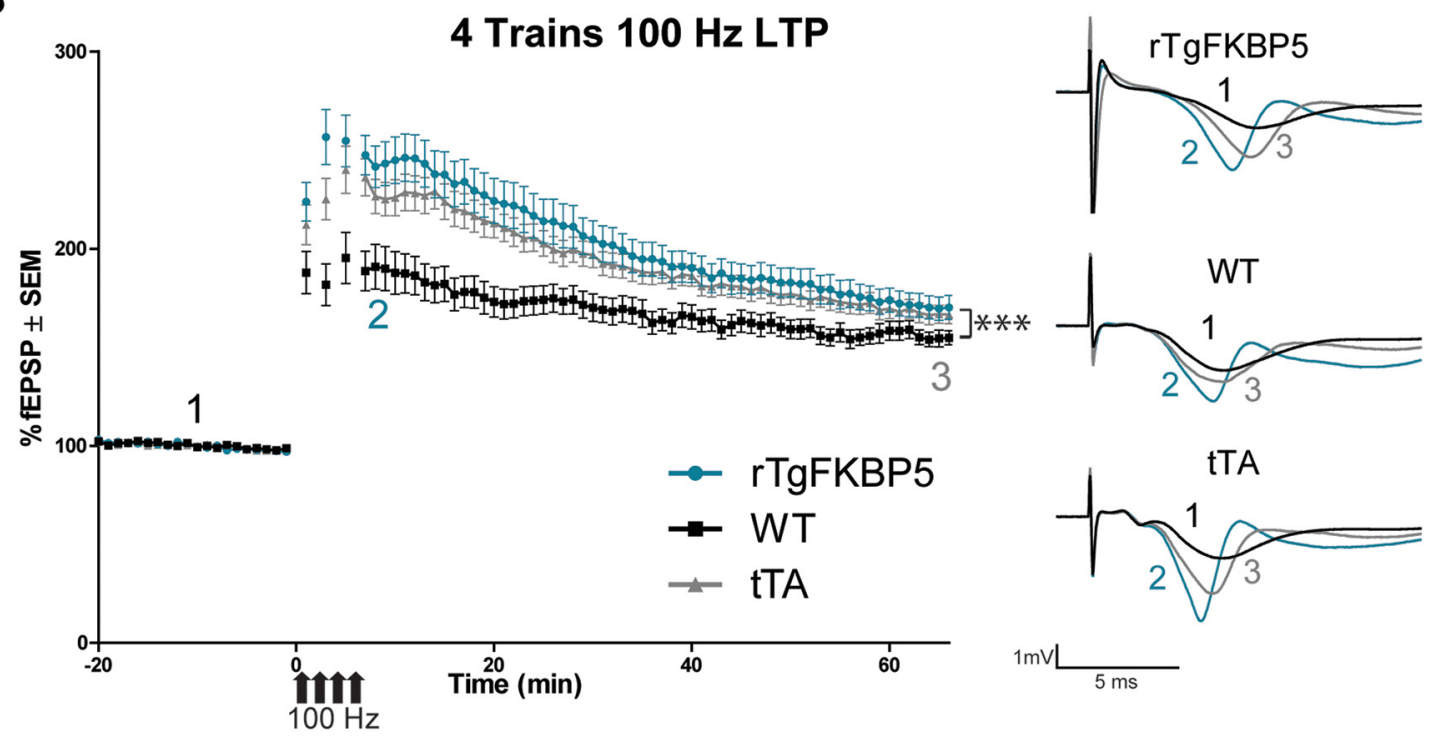

Figure 5. FKBP51 overexpression modestly alters LTP induction and maintenance. Ex vivo hippocampal slices from rTgFKBP5 and littermate controls were prepared for LTP testing in the Schaffer collateral pathway. Following a 20-min baseline, slices were stimulated by one-train $(\boldsymbol{A})$ or four-trains $(\boldsymbol{B})$ of HFS at $100 \mathrm{~Hz}$ to induce LTP. Evoked fEPSPs \pm SEM, normalized to baseline, were measured for $60 \mathrm{~min}$ following HFS. In the one-train protocol, slices from rTgFKBP5 $(N=5)$, WT $(N=6)$, and tTA $(N=5)$ mice were used. In the four-train protocol, rTgFKBP5 $(N=7)$, WT $(N=6)$, and tTA $(N=8)$ mice were used. Representative traces are shown: 1 (black) indicates baseline, 2 (teal) indicates initial early LTP potentiation in the first 3 min following potentiation, and 3 (gray) indicates late LTP in the last 3 min of recording. $* p<0.0001$ by one-way ANOVA with Tukey's Multiple Comparison's test of the last 5 minutes. $* * * p<0.0001$ by two-way ANOVA.

tain intense memories of a traumatic event. While future studies are still needed to better understand these connections, our findings suggest that FKBP51 could contribute to a number of age-related cognitive pathologies, possibly partly through a role in regulating AMPA receptor recycling and synaptic plasticity.

Unlike FKBP51, Hsp90 has been previously revealed to be necessary for synaptic protein recycling and neurotransmitter release (Gerges et al., 2004; Chen et al., 2014), our results show that levels of Hsp90 cochaperones can influence receptor fate as well. It is likely that Hsp90 coordinates directly with FKBP51 as well as other TPR containing co-chaperones, like FKBP52 and cyclophilin 40, to interact with glutamate receptors and influence synaptic function. In addition, Hsp90 has been shown to coordinate with the heat shock cognate (Hsc) 70/cysteine string protein $\alpha(\mathrm{CSP} \alpha)$ complex at the synaptic membrane to regulate clathrin-dependent endocytosis of glutamate receptors (Jiménez et al., 2002; Sakisaka et al., 2002; Cottrell et al., 2004).

Chaperone-mediated synaptic trafficking has also been implicated in neurodegenerative disease (Gerges et al., 2004; Köroğlu et al., 2013; Chen et al., 2014; VilariñoGüell et al., 2014). For example, mutations in the Hsp70 
A

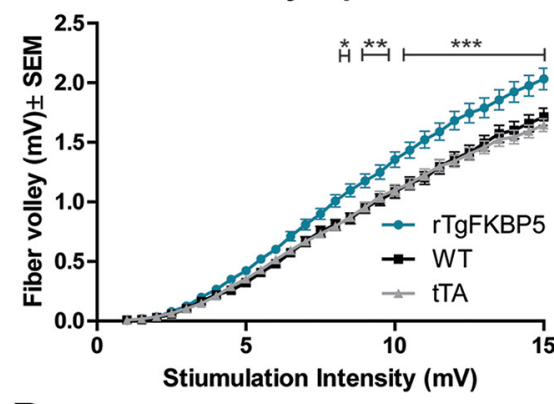

B

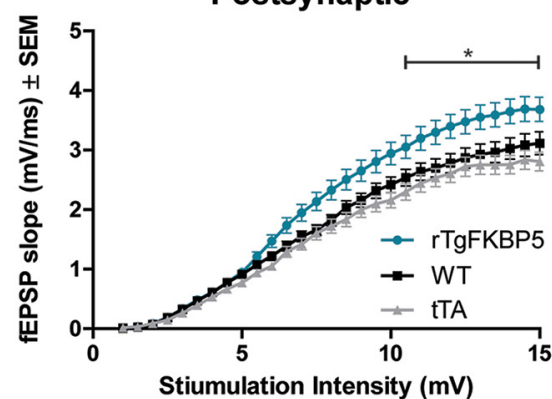

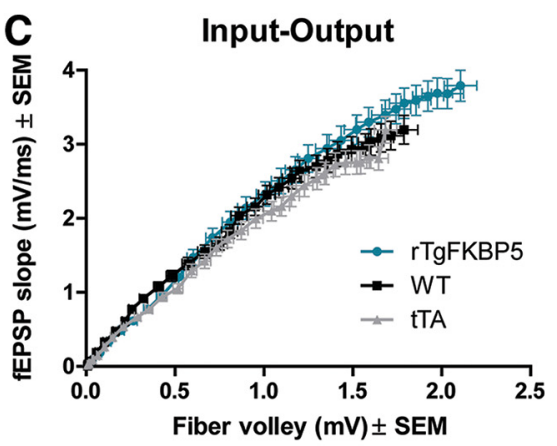

PPF

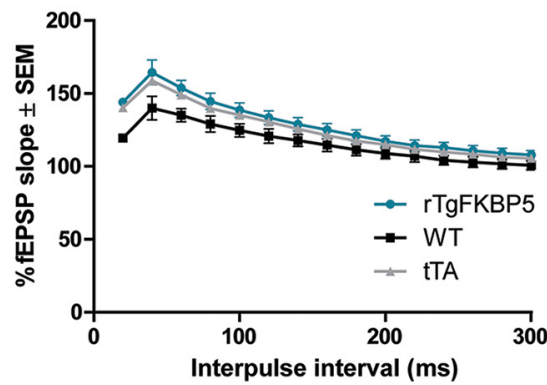

Figure 6. FKBP51 overexpression alters basal AMPA receptor signaling. Following 10 min of consistent response to voltage stimulus, threshold voltage for evoking a fEPSP was measured. Voltage was progressively increased at a rate of $0.5 \mathrm{mV}$ until the maximum fEPSP was reached. The absolute I-O curves of the $(\boldsymbol{A})$ presynaptic fiber volley amplitude $(\mathrm{mV}) \pm \mathrm{SEM}$ and $(\boldsymbol{B})$ postsynaptic $\mathrm{fEPSP}$ slope $(\mathrm{mV} / \mathrm{ms})$ \pm SEM from rTgFKBP5 $(N=15)$, WT $(N=15)$, and tTA $(N=19)$ mice. Significance was determined by two-way ANOVA. $\boldsymbol{C}$, The I-O curves of the fEPSP slope $(\mathrm{mV} / \mathrm{ms}) \pm$ SEM versus the fiber volley amplitude $(\mathrm{mV}) \pm \mathrm{SEM}$. Representative traces of the I-O for each genotype are shown with 1 representing fiber volley and 2 representing the fEPSP. $D$, The PPF from rTgFKBP5 $(N=31)$, WT $(N=33)$, and tTA $(N=30)$ is shown, which is derived from the ratio of the slope of the first peak to the slope of the second peak, over the interstimulus interval (ms). Significance was determined by two-way ANOVA. $* p<0.05, * * p<0.01, * * * p<0.0001$ by two-way ANOVA.

co-chaperones DNAJC13 and DNAJC6 that reduce clathrin-mediated endocytosis cause Parkinson's disease (Köroğlu et al., 2013; Vilariño-Güell et al., 2014). Also, the endoplasmic reticulum (ER) resident Hsp90, glucose- regulated protein 94 (Grp94), impairs the trafficking of a mutant, aggregation-prone protein to the lysosome, causing it to accumulate and promote hereditary glaucoma (Suntharalingam et al., 2012). More generally, chaperone

\section{LTD}
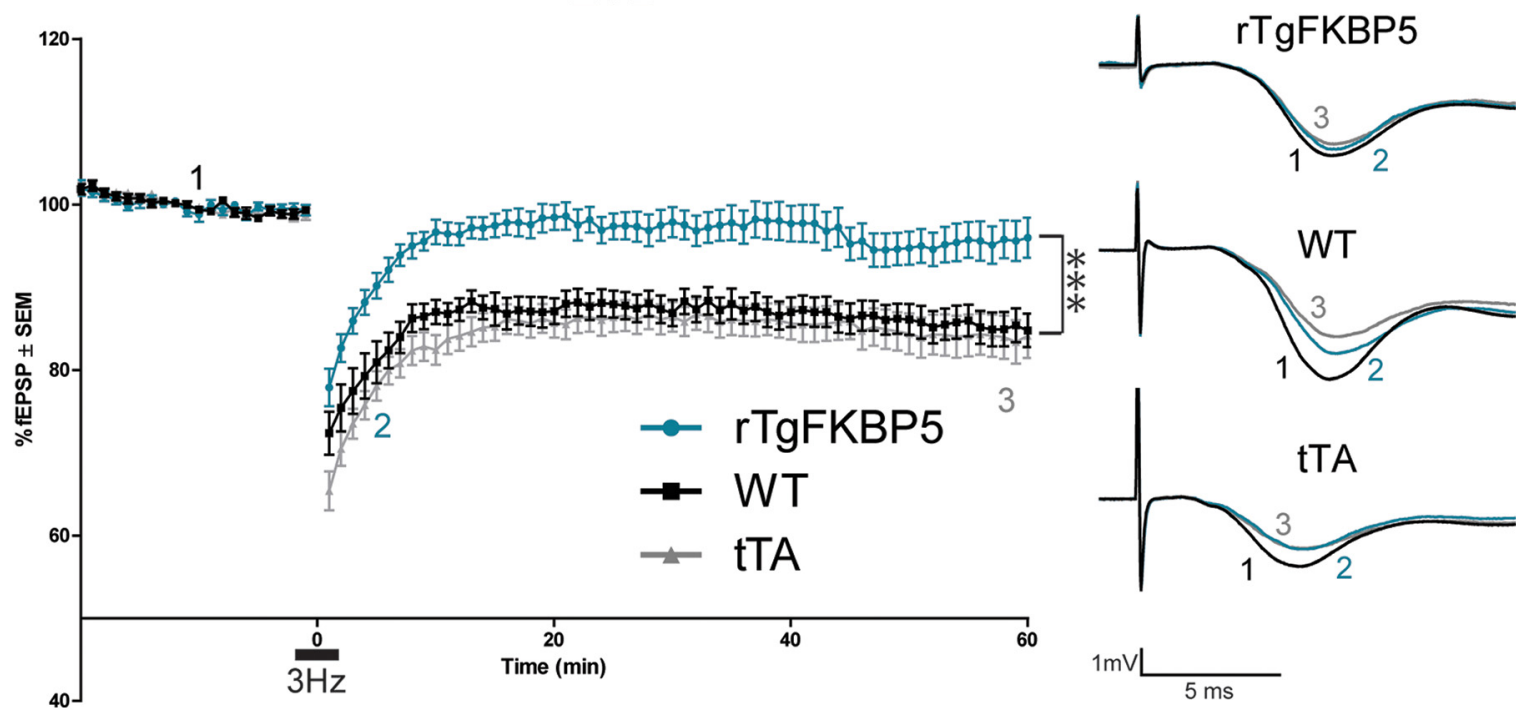

Figure 7. LTD is impaired in rTgFKBP5 mice. LTD fEPSP (\%) \pm SEM was induced following 20-min baseline recording in ex vivo slices from rTgFKBP5 $(N=9)$, WT $(N=9)$, and tTA $(N=10)$ mice by 900 pulses of low-frequency $(3 \mathrm{~Hz})$ stimulation. Representative traces are shown: 1 (black) indicates baseline, 2 (teal) indicates early LTD, and 3 (gray) indicates late LTD; ***p $<0.001$ determined by two-way ANOVA. 
A

Internalized Receptors

$\operatorname{NMDA}(20 \mu \mathrm{M}) \frac{\text { rTgFKBP5 }}{}$

$\begin{array}{lllllll}\text { Endocytosis Time (min) } & 0 & 0 & 2 & 5 & 10 & 30\end{array}$

Internalized GluR1 _ _ _ _ _ - $-100 \mathrm{kDa}$

$\operatorname{NMDA}(20 \mu \mathrm{M}) \frac{\text { WT }+ \text { tTA }}{$\cline { 2 - 2 }++++}

Endocytosis Time (min) $0 \begin{array}{llllll}0 & 0 & 2 & 5 & 10 & 30\end{array}$

Internalized GluR1 _ _ _ _
B

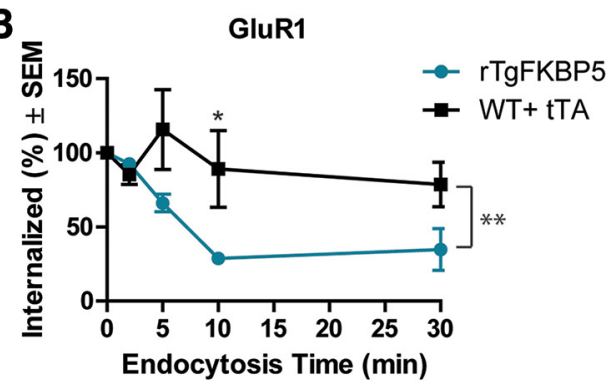

C

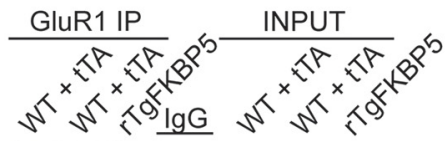

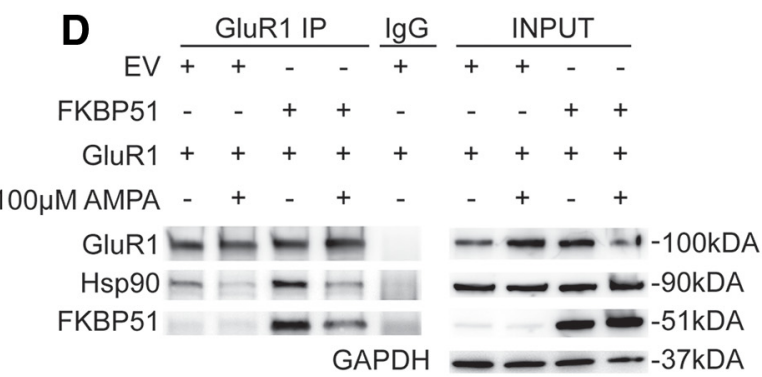

Figure 8. FKBP51/Hsp90 bind to GluR1-type AMPA receptors to regulate trafficking. $\boldsymbol{A}$, Representative Western blottings form biotinylation assays of receptor endocytosis was performed on ex vivo slices, as described in Materials and Methods, rTgFKBP5 ( $N$ $=4 ; n=8)$, WT $(N=2 ; n=8)$, and tTA $(N=2 ; n=8)$. Following labeling with Sulfo-NHS-SS biotin and chemical LTD (20 $\mu$ M NMDA; $5 \mathrm{~min}$ ) treatment, receptors were permitted to externalize at $30^{\circ} \mathrm{C}$ for the indicated times. $\boldsymbol{B}$, The quantification $\pm \mathrm{SEM}$ of multiple acquisitions is shown for GluR1. C, Representative Western blottings from anti-GluR1 co-immunoprecipitations and corresponding inputs from control and rTgFKBP5 mice immunoblotted as indicated. rTgFKBP5 $(N=2)$, WT $(N=2)$, and tTA $(N=2)$ total from two independent experiments. $\boldsymbol{D}$, Representative Western blottings of anti-GluR1 co-immunoprecipitations and corresponding inputs from HEK293T cells transfected with GluR1 and FKBP51 or empty vector (EV) for $48 \mathrm{~h}$ were immunoblotted with antibodies as indicated. Just before harvest, cells were treated with $100 \mu \mathrm{M}$ AMPA or PBS for 10 min to induce GluR1 receptor internalization. $* p=0.0286$ by t-test of this time point. $* * p<0.001$ by two-way ANOVA.

dysfunction has been linked to the trafficking of proteins between distinct organelles in disease. For example, despite still being functional, mutant cystic fibrosis transmembrane conductance regulator (CFTR) is trafficked out of the ER for degradation by Hsp90 when in complex with its co-chaperone Aha1 resulting in disease (Wang et al., 2006). Now, in light of our findings, TPR-containing chaperones also play a critical role in chaperonemediated synaptic trafficking. In fact, in a recent study in postmortem human brains, Young et al. (2015) suggested that FKBP51 may regulate neuronal spine densities. It is possible that the increased levels of FKBP51 measured by that study impaired spine morphogenesis directly altered AMPA receptor recycling, since spine
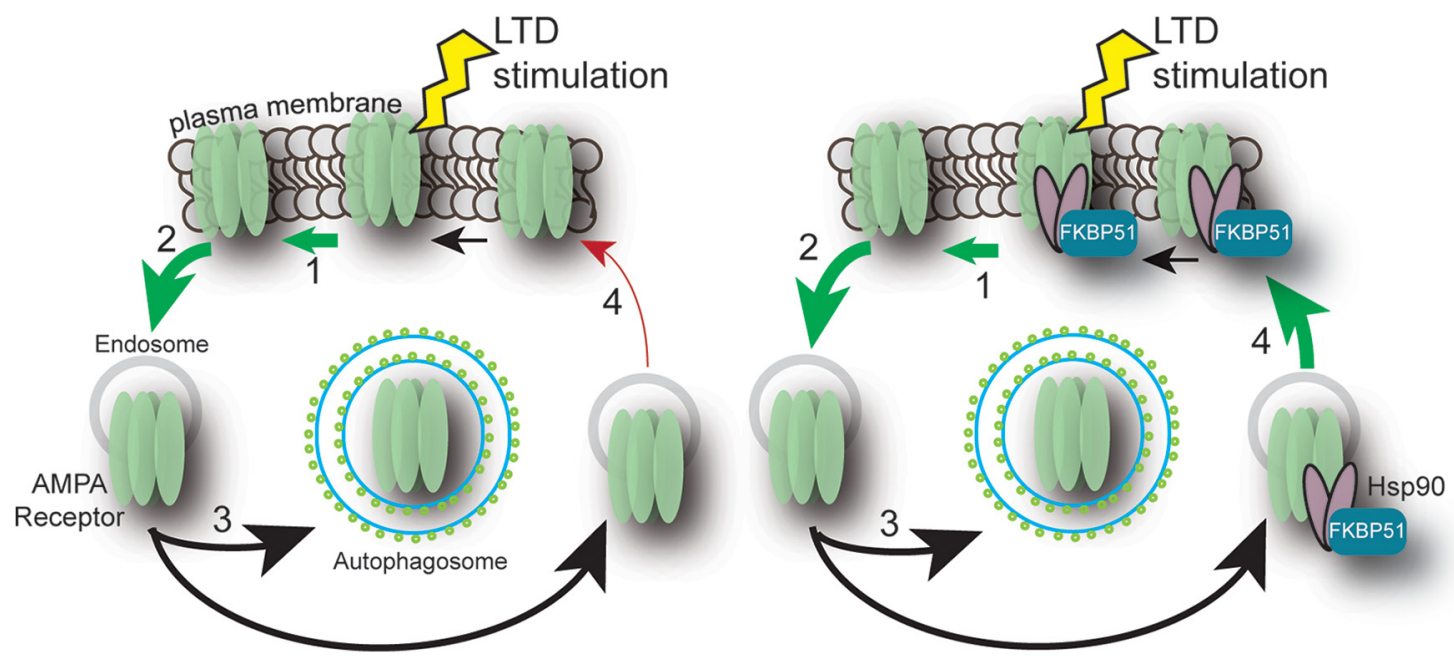

Figure 9. Working schematic of FKBP51/Hsp90 regulation of AMPA receptor recycling. Upon LTD stimulation, AMPA receptors are (1) moved away from the synapse and (2) internalized, following internalization either degraded through (3) macroautophagy or (4) recycled back to the membrane. LTD is expressed when the rate of internalization is greater than the rate of exocytosis. In the presence of high levels of FKBP51, Hsp90 binds to GluR1 and drives more AMPA receptors to be recycled back to the membrane. 
size and density can be directly regulated by AMPA receptor trafficking (Matsuzaki et al., 2004). Thus, the function of chaperones appears to extend beyond regulation of protein folding to vital and dynamic synaptic trafficking mechanisms.

Efforts to better understand the AMPA receptor cycle have recently been under intense investigation. Internalized AMPA receptors are trafficked to the early endosome where they are either transferred to the lysosome for degradation or to the recycling endosomes (REs) as a replenishment pool for membrane reinsertion (Ehlers, 2000). But our understanding of the mechanism contributing to these processes remains limited. It is known that posttranslational modifications, such as palmitoylation, ubiquitination, and most notably phosphorylation, regulate AMPA receptor trafficking. AMPA receptor trafficking is also regulated by interactions with a variety of AMPA receptor interacting proteins (Anggono and Huganir, 2012; Lu and Roche, 2012). Stability of AMPA receptors within the synaptic membrane is supported by a number of these interacting proteins including: postsynaptic density (PSD)-95, stargazin, glutamate receptor-interacting protein (GRIP)1, GRIP2, and synaptic associated protein (SAP)97. AMPA receptor endocytosis is promoted by PICK1 (Lu and Roche, 2012), which coordinates with protein kinase $\mathrm{C}$ and casein kinase II substrate in neurons (PACSIN) during synaptic activity to regulate the internalization and recycling of AMPA receptors (Widagdo et al., 2016). Transferrin receptor (TFR) also promotes endocytosis of AMPA receptors in synaptically active neurons (Liu et al., 2016). Until recently, less has been known about the recycling arm of AMPA receptor trafficking. N-ethymaleimide-sensitive factor (NSF; Huganir and Nicoll, 2013), the $\mu 3 \mathrm{~A}$ subunit of AP-3 (Steinmetz et al., 2016), and KIBRA (Heitz et al., 2016) all can promote recycling of AMPA receptors. $\mu 3 \mathrm{~A}$, KIBRA and now FKBP51 have each been shown to specifically regulate recycling of GluR1-type AMPA receptors following activity dependent internalization. Thus, our findings identify a novel regulator of the decisionmaking process governing GluR1-type AMPA receptor trafficking in active synapses.

We were surprised that FKBP51 overexpression did not lead to more phenotypes related to depression-like and anxiety-like behaviors. We hypothesize these phenotypes may be precipitated in the rTgFKBP5 model in the presences of environmental factors, such as stress. It is also possible that we did see these phenotypes due to limitations in our current study, such as using both male and female mice throughout, the location of FKBP51 expression, or the age of the mice. Follow-up studies are needed in this model using different Tet driving promoters as well as careful investigation in to the combinatory effects of environmental factors, including stress, as well as sexrelated differences to better illuminate how alterations in FKBP51 may increase susceptibility of PTSD, depression, and other psychiatric disorders.

In conclusion, our results support a model in which FKBP51 promotes the regulation of GluR1-type AMPA receptor trafficking through Hsp90 leading to altered neu- rotransmission and reduced cognitive flexibility in rTgFKBP5 mice. In this way, disease-associated SNPs and stressors that increase FKBP5 expression can influence the brain in an unexpected way. Not only can FKBP51 regulate GR activity (Rein, 2016), but it may also have a major impact on glutamatergic neurotransmission and synaptic plasticity.

\section{References}

Anggono V, Huganir RL (2012) Regulation of AMPA receptor trafficking and synaptic plasticity. Curr Opin Neurobiol 22:461-469. CrossRef Medline

Attwood BK, Bourgognon JM, Patel S, Mucha M, Schiavon E, Skrzypiec AE, Young KW, Shiosaka S, Korostynski M, Piechota M, Przewlocki R, Pawlak R (2011) Neuropsin cleaves EphB2 in the amygdala to control anxiety. Nature 473:372-375. CrossRef Medline

Bailey KR, Crawley JN (2009) Anxiety-related behaviors in mice. In: Methods of behavior analysis in neuroscience (Buccafusco JJ, ed), Ed 2. Boca Raton, FL: CRC Press/Taylor \& Francis.

Bevilacqua L, Carli V, Sarchiapone M, George DK, Goldman D, Roy A, Enoch MA (2012) Interaction between FKBP5 and childhood trauma and risk of aggressive behavior. Arch Gen Psychiatry 69:62-70. CrossRef Medline

Binder EB, Salyakina D, Lichtner P, Wochnik GM, Ising M, Pütz B, Papiol S, Seaman S, Lucae S, Kohli MA, Nickel T, Künzel HE, Fuchs B, Majer M, Pfennig A, Kern N, Brunner J, Modell S, Baghai T, Deiml T, et al. (2004) Polymorphisms in FKBP5 are associated with increased recurrence of depressive episodes and rapid response to antidepressant treatment. Nat Genet 36:1319-1325. CrossRef Medline

Binder EB, Bradley RG, Liu W, Epstein MP, Deveau TC, Mercer KB, Tang Y, Gillespie CF, Heim CM, Nemeroff CB, Schwartz AC, Cubells JF, Ressler KJ (2008) Association of FKBP5 polymorphisms and childhood abuse with risk of posttraumatic stress disorder symptoms in adults. JAMA 299:1291-1305. CrossRef Medline

Blair LJ, Nordhues BA, Hill SE, Scaglione KM, O'Leary JC 3rd, Fontaine SN, Breydo L, Zhang B, Li P, Wang L, Cotman C, Paulson HL, Muschol M, Uversky VN, Klengel T, Binder EB, Kayed R, Golde TE, Berchtold N, Dickey CA (2013) Accelerated neurodegeneration through chaperone-mediated oligomerization of tau. J Clin Invest 123:4158-4169. CrossRef Medline

Chen Y, Wang B, Liu D, Li JJ, Xue Y, Sakata K, Zhu LQ, Heldt SA, Xu H, Liao FF (2014) Hsp90 chaperone inhibitor 17-AAG attenuates $\mathrm{A} \beta$-induced synaptic toxicity and memory impairment. $J$ Neurosci 34:2464-2470. CrossRef Medline

Cottrell JR, Borok E, Horvath TL, Nedivi E (2004) CPG2: a brain- and synapse-specific protein that regulates the endocytosis of glutamate receptors. Neuron 44:677-690. CrossRef Medline

Dong Z, Bai Y, Wu X, Li H, Gong B, Howland JG, Huang Y, He W, Li T, Wang YT (2013) Hippocampal long-term depression mediates spatial reversal learning in the Morris water maze. Neuropharmacology 64:65-73. CrossRef Medline

Ehlers MD (2000) Reinsertion or degradation of AMPA receptors determined by activity-dependent endocytic sorting. Neuron 28: 511-525. CrossRef Medline

Fujii T, Ota M, Hori H, Hattori K, Teraishi T, Matsuo J, Kinoshita Y, Ishida I, Nagashima A, Kunugi H (2014) The common functional FKBP5 variant rs 1360780 is associated with altered cognitive function in aged individuals. Sci Rep 4:6696. CrossRef Medline

Gajewski PD, Wild-Wall N, Schapkin SA, Erdmann U, Freude G, Falkenstein M (2010) Effects of aging and job demands on cognitive flexibility assessed by task switching. Biol Psychol 85:187199. CrossRef Medline

Gassen NC, Hartmann J, Zschocke J, Stepan J, Hafner K, Zellner A, Kirmeier T, Kollmannsberger L, Wagner KV, Dedic N, Balsevich G, Deussing JM, Kloiber S, Lucae S, Holsboer F, Eder M, Uhr M, Ising 
M, Schmidt MV, Rein T (2014) Association of FKBP51 with priming of autophagy pathways and mediation of antidepressant treatment response: evidence in cells, mice, and humans. PLoS Med 11: e1001755. CrossRef Medline

Gassen NC, Hartmann J, Schmidt MV, Rein T (2015) FKBP5/FKBP51 enhances autophagy to synergize with antidepressant action. Autophagy 11:578-580. CrossRef Medline

Gerges NZ, Tran IC, Backos DS, Harrell JM, Chinkers M, Pratt WB, Esteban JA (2004) Independent functions of hsp90 in neurotransmitter release and in the continuous synaptic cycling of AMPA receptors. J Neurosci 24:4758-4766. CrossRef Medline

Glisky EL (2007) Changes in cognitive function in human aging. In: Brain aging: models, methods, and mechanisms (Riddle DR, ed). Boca Raton, FL: CRC Press/Taylor \& Francis.

Gross KL, Westberry JM, Hubler TR, Sadosky PW, Singh RJ, Taylor $\mathrm{RL}$, Scammell JG (2008) Androgen resistance in squirrel monkeys (Saimiri spp.). Comp Med 58:381-388. Medline

Han HJ, Allen CC, Buchovecky CM, Yetman MJ, Born HA, Marin MA, Rodgers SP, Song BJ, Lu HC, Justice MJ, Probst FJ, Jankowsky JL (2012) Strain background influences neurotoxicity and behavioral abnormalities in mice expressing the tetracycline transactivator. J Neurosci 32:10574-10586. CrossRef Medline

Hartmann J, Wagner KV, Liebl C, Scharf SH, Wang XD, Wolf M, Hausch F, Rein T, Schmidt U, Touma C, Cheung-Flynn J, Cox MB, Smith DF, Holsboer F, Müller MB, Schmidt MV (2012) The involvement of FK506-binding protein 51 (FKBP5) in the behavioral and neuroendocrine effects of chronic social defeat stress. Neuropharmacology 62:332-339. CrossRef Medline

Hartmann J, Wagner KV, Gaali S, Kirschner A, Kozany C, Ruhter G, Dedic N, Hausl AS, Hoeijmakers L, Westerholz S, Namendorf C, Gerlach T, Uhr M, Chen A, Deussing JM, Holsboer F, Hausch F, Schmidt MV (2015) Pharmacological inhibition of the psychiatric risk factor FKBP51 has anxiolytic properties. J Neurosci 35:90079016. CrossRef Medline

Heitz FD, Farinelli M, Mohanna S, Kahn M, Duning K, Frey MC, Pavenstadt $\mathrm{H}$, Mansuy IM (2016) The memory gene KIBRA is a bidirectional regulator of synaptic and structural plasticity in the adult brain. Neurobiol Learn Mem 135:100-114. CrossRef Medline

Huganir RL, Nicoll RA (2013) AMPARs and synaptic plasticity: the last 25 years. Neuron 80:704-717. CrossRef Medline

Jiménez CR, Eyman M, Lavina ZS, Gioio A, Li KW, van der Schors RC, Geraerts WP, Giuditta A, Kaplan BB, van Minnen J (2002) Protein synthesis in synaptosomes: a proteomics analysis. J Neurochem 81:735-744. Medline

Jinwal UK, Koren J 3rd, Borysov SI, Schmid AB, Abisambra JF, Blair LJ, Johnson AG, Jones JR, Shults CL, O'Leary JC 3rd, Jin Y, Buchner J, Cox MB, Dickey CA (2010) The Hsp90 cochaperone, FKBP51, increases tau stability and polymerizes microtubules. $J$ Neurosci 30:591-599. CrossRef Medline

Kelly PT, Vernon P (1985) Changes in the subcellular distribution of calmodulin-kinase II during brain development. Brain Res 350: 211-224. Medline

Klengel T, Mehta D, Anacker C, Rex-Haffner M, Pruessner JC, Pariante CM, Pace TW, Mercer KB, Mayberg HS, Bradley B, Nemeroff CB, Holsboer F, Heim CM, Ressler KJ, Rein T, Binder EB (2013) Allele-specific FKBP5 DNA demethylation mediates genechildhood trauma interactions. Nat Neurosci 16:33-41. CrossRef Medline

Kopec CD, Li B, Wei W, Boehm J, Malinow R (2006) Glutamate receptor exocytosis and spine enlargement during chemically induced long-term potentiation. J Neurosci 26:2000-2009. CrossRef Medline

Köroğlu C, Baysal L, Cetinkaya M, Karasoy H, Tolun A (2013) DNAJC6 is responsible for juvenile parkinsonism with phenotypic variability. Parkinsonism Relat Disord 19:320-324. CrossRef

Lee HK, Kameyama K, Huganir RL, Bear MF (1998) NMDA induces long-term synaptic depression and dephosphorylation of the GluR1 subunit of AMPA receptors in hippocampus. Neuron 21: 1151-1162. CrossRef Medline
Lee HK, Min SS, Gallagher M, Kirkwood A (2005) NMDA receptorindependent long-term depression correlates with successful aging in rats. Nat Neurosci 8:1657-1659. CrossRef Medline

Lee HK, Takamiya K, He K, Song L, Huganir RL (2010) Specific roles of AMPA receptor subunit GluR1 (GluA1) phosphorylation sites in regulating synaptic plasticity in the CA1 region of hippocampus. $J$ Neurophysiol 103:479-489. CrossRef Medline

Liu K, Lei R, Li Q, Wang XX, Wu Q, An P, Zhang J, Zhu M, Xu Z, Hong Y, Wang F, Shen Y, Li H, Li H (2016) Transferrin receptor controls AMPA receptor trafficking efficiency and synaptic plasticity. Sci Rep 6:21019. CrossRef Medline

Livak KJ, Schmittgen TD (2001) Analysis of relative gene expression data using real-time quantitative PCR and the 2(-delta delta $\mathrm{C}(\mathrm{T})$ ) method. Methods 25:402-408. CrossRef Medline

Lu W, Roche KW (2012) Posttranslational regulation of AMPA receptor trafficking and function. Curr Opin Neurobiol 22:470-479. CrossRef Medline

Luscher C, Malenka RC (2012) NMDA receptor-dependent long-term potentiation and long-term depression (LTP/LTD). Cold Spring Harb Perspect Biol 4. pii: a005710. CrossRef Medline

Matsuzaki M, Honkura N, Ellis-Davies GC, Kasai H (2004) Structural basis of long-term potentiation in single dendritic spines. Nature 429:761-766. CrossRef Medline

Mayford M, Bach ME, Huang YY, Wang L, Hawkins RD, Kandel ER (1996) Control of memory formation through regulated expression of a CaMKII transgene. Science 274:1678-1683. CrossRef Medline

Nair SC, Rimerman RA, Toran EJ, Chen S, Prapapanich V, Butts RN, Smith DF (1997) Molecular cloning of human FKBP51 and comparisons of immunophilin interactions with Hsp90 and progesterone receptor. Mol Cell Biol 17:594-603. CrossRef Medline

O'Leary JC 3rd, Dharia S, Blair LJ, Brady S, Johnson AG, Peters M, Cheung-Flynn J, Cox MB, de Erausquin G, Weeber EJ, Jinwal UK, Dickey CA (2011) A new anti-depressive strategy for the elderly: ablation of FKBP5/FKBP51. PLoS One 6:e24840. CrossRef Medline

Peineau S, Taghibiglou C, Bradley C, Wong TP, Liu L, Lu J, Lo E, Wu $D$, Saule E, Bouschet T, Matthews P, Isaac JT, Bortolotto ZA, Wang YT, Collingridge GL (2007) LTP inhibits LTD in the hippocampus via regulation of GSK3beta. Neuron 53:703-717. CrossRef Medline

Potier B, Turpin FR, Sinet PM, Rouaud E, Mothet JP, Videau C, Epelbaum J, Dutar P, Billard JM (2010) Contribution of the d-serine-dependent pathway to the cellular mechanisms underlying cognitive aging. Front Aging Neurosci 2:1. CrossRef Medline

Rein T (2016) FK506 binding protein 51 integrates pathways of adaptation: FKBP51 shapes the reactivity to environmental change. Bioessays 38:894-902. CrossRef Medline

Sabbagh JJ, O'Leary JC 3rd, Blair LJ, Klengel T, Nordhues BA, Fontaine SN, Binder EB, Dickey CA (2014) Age-associated epigenetic upregulation of the FKBP5 gene selectively impairs stress resiliency. PLoS One 9:e107241. CrossRef Medline

Sakisaka T, Meerlo T, Matteson J, Plutner H, Balch WE (2002) Rab-alphaGDI activity is regulated by a Hsp90 chaperone complex. EMBO J 21:6125-6135. CrossRef Medline

Schmidt MV, Schülke JP, Liebl C, Stiess M, Avrabos C, Bock J, Wochnik GM, Davies HA, Zimmermann N, Scharf SH, Trümbach D, Wurst W, Zieglgänsberger W, Turck C, Holsboer F, Stewart MG, Bradke F, Eder M, Müller MB, Rein T (2011) Tumor suppressor down-regulated in renal cell carcinoma 1 (DRR1) is a stressinduced actin bundling factor that modulates synaptic efficacy and cognition. Proc Natl Acad Sci USA 108:17213-17218. CrossRef Medline

Schoenfeld R, Foreman N, Leplow B (2014) Ageing and spatial reversal learning in humans: findings from a virtual water maze. Behav Brain Res 270:47-55. CrossRef Medline

Steinmetz CC, Tatavarty V, Sugino K, Shima Y, Joseph A, Lin H, Rutlin M, Lambo M, Hempel CM, Okaty BW, Paradis S, Nelson SB, Turrigiano GG (2016) Upregulation of mu3A drives homeostatic 
plasticity by rerouting AMPAR into the recycling endosomal pathway. Cell Rep 16:2711-2722. CrossRef Medline

Strekalova T, Couch Y, Kholod N, Boyks M, Malin D, Leprince P, Steinbusch HM (2011) Update in the methodology of the chronic stress paradigm: internal control matters. Behav Brain Funct 7:9. CrossRef Medline

Suntharalingam A, Abisambra JF, O'Leary JC 3rd, Koren J 3rd, Zhang B, Joe MK, Blair LJ, Hill SE, Jinwal UK, Cockman M, Duerfeldt AS, Tomarev S, Blagg BS, Lieberman RL, Dickey CA (2012) Glucose-regulated protein 94 triage of mutant myocilin through endoplasmic reticulum-associated degradation subverts a more efficient autophagic clearance mechanism. J Biol Chem 287:40661-40669. CrossRef Medline

Tasic B, Hippenmeyer S, Wang C, Gamboa M, Zong H, Chen-Tsai Y, Luo $L$ (2011) Site-specific integrase-mediated transgenesis in mice via pronuclear injection. Proc Natl Acad Sci USA 108:7902-7907. CrossRef Medline

Touma C, Gassen NC, Herrmann L, Cheung-Flynn J, Büll DR, lonescu IA, Heinzmann JM, Knapman A, Siebertz A, Depping AM, Hartmann J, Hausch F, Schmidt MV, Holsboer F, Ising M, Cox MB, Schmidt U, Rein T (2011) FK506 binding protein 5 shapes stress responsiveness: modulation of neuroendocrine reactivity and coping behavior. Biol Psychiatry 70:928-936. CrossRef Medline

Tyrka AR, Ridout KK, Parade SH, Paquette A, Marsit CJ, Seifer R (2015) Childhood maltreatment and methylation of FK506 binding protein 5 gene (FKBP5). Dev Psychopathol 27:1637-1645. CrossRef Medline

Vilariño-Güell C, Rajput A, Milnerwood AJ, Shah B, Szu-Tu C, Trinh J, Yu I, Encarnacion M, Munsie LN, Tapia L, Gustavsson EK, Chou P, Tatarnikov I, Evans DM, Pishotta FT, Volta M, Beccano-Kelly D, Thompson C, Lin MK, Sherman HE, et al. (2014) DNAJC13 mutations in Parkinson disease. Hum Mol Genet 23:1794-1801. CrossRef Medline

Wang $L$ (2011) FKBP51 regulation of AKT/protein kinase B phosphorylation. Curr Opin Pharmacol 11:360-364. CrossRef Medline

Wang X, Venable J, LaPointe P, Hutt DM, Koulov AV, Coppinger J, Gurkan C, Kellner W, Matteson J, Plutner H, Riordan JR, Kelly JW,
Yates JR 3rd, Balch WE (2006) Hsp90 cochaperone Aha1 downregulation rescues misfolding of CFTR in cystic fibrosis. Cell 127: 803-815. CrossRef Medline

Wang X, Zhang C, Szábo G, Sun QQ (2013) Distribution of CaMKIll $\alpha$ expression in the brain in vivo, studied by CaMKIl $\alpha$-GFP mice. Brain Res 1518:9-25. CrossRef Medline

Wei Q, Lu XY, Liu L, Schafer G, Shieh KR, Burke S, Robinson TE, Watson SJ, Seasholtz AF, Akil H (2004) Glucocorticoid receptor overexpression in forebrain: a mouse model of increased emotional lability. Proc Natl Acad Sci USA 101:11851-11856. CrossRef Medline

Wichers MC, Barge-Schaapveld DQ, Nicolson NA, Peeters F, de Vries M, Mengelers R, van Os J (2009) Reduced stress-sensitivity or increased reward experience: the psychological mechanism of response to antidepressant medication. Neuropsychopharmacology 34:923-931. CrossRef Medline

Widagdo J, Fang H, Jang SE, Anggono V (2016) PACSIN1 regulates the dynamics of AMPA receptor trafficking. Sci Rep 6:31070. CrossRef Medline

Young KA, Thompson PM, Cruz DA, Williamson DE, Selemon LD (2015) BA11 FKBP5 expression levels correlate with dendritic spine density in postmortem PTSD and controls. Neurobiol Stress 2:67-72. CrossRef Medline

Zannas AS, Wiechmann T, Gassen NC, Binder EB (2016) Genestress-epigenetic regulation of FKBP5: clinical and translational implications. Neuropsychopharmacology 41:261-274. CrossRef Medline

Zhang J, Hou L, Klann E, Nelson DL (2009) Altered hippocampal synaptic plasticity in the FMR1 gene family knockout mouse models. J Neurophysiol 101:2572-2580. CrossRef Medline

Zheng D, Sabbagh JJ, Blair LJ, Darling AL, Wen X, Dickey CA (2016) MicroRNA-511 binds to FKBP5 mRNA, which encodes a chaperone protein, and regulates neuronal differentiation. J Biol Chem 291:17897-17906. CrossRef Medline

Zucker RS, Regehr WG (2002) Short-term synaptic plasticity. Annu Rev Physiol 64:355-405. CrossRef Medline 